\title{
KONSEP DESAIN APLIKASI SISTEM MANAJEMEN KEPEGAWAIAN BERBASIS WEB PADA PT. BINTANG KOMUNIKASI UTAMA \\ (Application design concept of web-based staffing management system at PT Bintang Komunikasi Utama)
}

\author{
Anggeri S.Nurjaman, Verdi Yasin \\ Verdi_yasin@stmik.jayakarta.ac.id \\ Program Studi Teknik Informatika, Fakultas Ilmu Komputer, Universitas Borobudur \\ Program Studi Teknik Informatika, STMIK Jayakarta, Jakarta
}

\begin{abstract}
ABSTRAK
Semangat kerja dapat diukur melalui kehadiran pegawai ditempat kerja, tanggung jawabnya terhadap pekerjaan, disiplin kerja dalam organisasi serta tingkat produktivitas kerjanya. Mengukur tinggi rendahnya semangat kerja pegawai meliputi tingkat kehadiran, disiplin kerja, kerja sama dan tanggung jawab. Presensi merupakan kehadiran pegawai yang berkenaan dengan tugas dan kewajibannya. Pada umumnya instansi atau lembaga selalu memperhatikan pegawainya untuk datang sehingga pekerjaan tidak tertunda. Untuk memperoleh kinerja yang optimal dari pegawai, maka organisasi perlu membuat dan menetapkan strategi yang berorientasi pada tujuan yang sama. Pada alat presensi pegawai model konvensional, memerlukan banyak hal dari pegawai bagian personalia maupun kejujuran pegawai. Hal ini bisa terjadi adanya manipulasi data kehadiran karyawan. Dengan sistem berbasis sidik jari, proses pengambilan data kehadiran pegawai mencapai $100 \%$ akurat karena data berdasarkan dari sidik jari karyawan langsung. Kesalahan dan manipulasi dapat dihindarkan karena pelaporanya menjadi otomatis dengan bantuan sistem. Tujuan dari model sistem manajemen kepegawaian ini sebagai media pengawasan dan media pendukung pengambilan keputusan untuk penilaian kinerja pegawai. Diharapkan memberi Solusi bagi perusahaan dalam Penilaian Kinerja Pegawai yang mampu menciptakan laporan dengan cepat, akurat dan real time.
\end{abstract}

Kata Kunci : Desain, Manajemen kepegawaian, Presensi, Sidik Jari.

\begin{abstract}
The spirit of work can be measured through the presence of employees in the workplace, their responsibility to work, discipline of work in the organization and the level of work productivity. Measuring the low morale of employees includes attendance level, discipline, cooperation and responsibility. Attendance is the presence of employees related to their duties and obligations. In general, agencies or agencies always pay attention to their employees to come so that work is not delayed. To obtain optimal performance from employees, organizations need to create and establish strategies that are oriented towards the same goal. In conventional model employee recruitment tools, requires a lot of things from personnel and honesty employees. This can occur in the manipulation of employee attendance data. With a fingerprint-based system, the process of retrieving employee attendance data reaches $100 \%$ accurate because the data is based on the fingerprints of direct employees. Errors and manipulations can be avoided because the reporting becomes automated with the help of the system. The purpose of this staffing management system model as a surveillance media and supporting media decision making for employee performance assessment. It is expected to provide solutions for companies in Employee Performance Assessment who are able to create reports quickly, accurately and in real time.
\end{abstract}

Keywords: Design, Staffing management, Review, Fingerprint.

\section{PENDAHULUAN}

Bagi organisasi atau perusahaan yang menggunakan Computer Based Information System (CBIS) atau Sistem Informasi Berbasis Komputer, jaringan memungkinkan komputer melaksanakan tugasnya dengan lebih cepat dan efisien. Pengolahan data dan informasi secara cepat, tepat dan efisien adalah hal penting yang dibutuhkan bagi lembaga atau instansi yaitu salah satunya adalah perusahaan.

Semangat kerja pegawai dapat diukur melalui kehadiran pegawai ditempat kerja, tanggung jawabnya

\section{JISICOM (Journal of Information System, Informatics and Computing)}

http://journal.stmikjayakarta.ac.id/index.php/jisicom Telp.+62-21-3905050, e-mail:jisicom@stmikjayakarta.ac.id, jisicom2017@gmail.com 
terhadap pekerjaan, disiplin kerja dalam organisasi serta tingkat produktivitas kerjanya. Untuk mengukur tinggi rendahnya semangat kerja pegawai dapat melalui unsurunsur semangat kerja tersebut yang meliputi presensi (tingkat kehadiran), disiplin kerja, kerja sama dan tanggung jawab. Presensi merupakan kehadiran pegawai yang berkenaan dengan tugas dan kewajibannya. Ketidakhadiran seorang pegawai akan berpengaruh terhadap produktivitas kerja, sehingga perusahaan tidak bisa mencapai tujuan secara optimal. Pada umumnya instansi atau lembaga selalu memperhatikan pegawainya untuk datang dan pulang tepat waktu, sehingga pekerjaan tidak tertunda.

Untuk memperoleh kinerja yang optimal dari pegawai, maka perusahaan perlu membuat dan menetapkan strategi yang berorientasi pada tujuan yang sama. Pada alat presensi pegawai model konvensional, memerlukan banyak hal dari pegawai bagian personalia maupun kejujuran pegawai. Hal ini bisa terjadi adanya manipulasi data kehadiran pegawai. Dengan sistem berbasis sidik jari, proses pengambilan data kehadiran pegawai mencapai $100 \%$ akurat karena data berdasarkan dari sidik jari pegawai langsung. Kesalahan dan manipulasi dapat dihindarkan karena pelaporanya menjadi otomatis dengan bantuan aplikasi sistem kepegawaian.

Tujuan dari model aplikasi sistem kepegawaian ini sebagai media pengawasan dan media pendukung pengambilan keputusan untuk penilaian kinerja pegawai. Yang diharapkan memberi Solusi bagi perusahaan dalam Penilaian Kinerja Pegawai yang mampu menciptakan laporan dengan cepat, akurat dan real time. Berdasarkan latar belakang yang penulis sampaikan diatas, beberapa poin yang penulis jadikan identifikasi masalah adalah sebagai berikut :

1. Manajemen data kepegawaian dalam bentuk digital yang terkomputerisasi sebagai pembaharuan sistem aplikasi lama.

2. Memonitoring aktivitas setiap pegawai.

3. Menyajikan laporan tentang kepegawaian secara cepat dan real time

\section{MATERIAL DAN METODE}

\subsection{Perancangan}

Perancangan pada dasarnya telah dideskripsikan sebagai proses banyak langkah dimana representasirepresentasi data dan struktur program, karakteristikkarakteristik antar muka dan rincian prosedural diikhtisarkan dari hal-hal yang berkaitan dengan kebutuhan-kebutuhan informasi.

Perancangan adalah sebuah proses untuk mendefinisikan sesuatu yang akan dikerjakan dengan menggunakan teknik yang bervariasi serta didalamnya melibatkan deskripsi mengenai arsitektur serta detail mengenai komponen dan juga keterbatasa yang akan dialami dalam proses pengerjaannya (Soetam Rizky. 2011).

Demikian pula menurut Roger S. Pressman (2010) mendefinisikan bahwa : "Perancangan yang sesungguhnya merupakan suatu aktivitas rekayasa perangkat lunak yang dimaksudkan untuk membuat keputusan-keputusan utama seringkali bersifat struktural".

Joseph Mansueto dalam buku pengurusan teknologi menyatakan bahwa "Perancangan adalah suatu proses untuk membuat keputusan tentang apa yang perlu dilakukan oleh organisasi". Berdsarkan pengertian diatas dapat diambil kesimpulan bahwa perancangan adalah :

1. Proses untuk mendefinisikan sesuatu yang melibatkan deskripsi mengenai arsitektur serta komponen.

2. Merupakan suatu aktivitas rekayasa perangkat lunak.

3. Membuat keputusan-keputusan utama yang bersifat struktural.

4. Merupakan penghubung antara kebutuhan dan implementasi.

\subsection{Implementasi}

Menurut Jeffri L. Pressman dan Aaron B. Wildavski mengartikan implementasi sebagai suatu proses interaksi antara suatu perangkat tujuan dan tindakan yang mampu untuk meraihnya. Implementasi adalah kemampuan membentuk hubungan lebih lanjut dalam rangkaian sebab-akibat yang menghubungkan tindakan dengan tujuan.

Secara sederhana implementasi bisa diartikan pelaksanaan atau penerapan, Majone dan Wiloldavsky mengemukakan implementasi sebagai evaluasi. Brone dan Wildavsky mengemukakan bahwa implementasi adalah perluasan aktivitas yang saling menyesuaikan. Pengertian implementasi sebagai aktivitas yang saling menyesuaikan juga dikemukakan oleh Mclughin. Adapun Albert Schubert mengemukakan bahwa implementasi adalah sistem rekayasa.

Pengertian-pengertian diatas memperlihatkan bahwa kata implementasi bermuara pada aktivitas, adanya aksi atau mekanisme suatu sistem. Ungkapan mekanisme mengandung arti bahwa implementasi bukan sekedar aktivitas, tetapi suatu kegiatan yang terencana dan dilakukan secara sungguh-sungguh berdasarkan acuan norma tertentu untuk mencapai tujuan kegiatan. Jadi

\section{JISICOM (Journal of Information System, Informatics and Computing)}

http://journal.stmikjayakarta.ac.id/index.php/jisicom Telp.+62-21-3905050, e-mail:jisicom@stmikjayakarta.ac.id, jisicom2017@gmail.com 
implementasi dapat juga diartikan mepresentasikan hasil desain ke dalam pemrograman.

\section{Aplikasi}

Aplikasi adalah suatu program yang siapa untuk digunakan yang dibuat untuk melaksanakan suatu fungsi bagi pengguna jasa aplikasi serta penggunaan lainnya yang dapat digunakan oleh suatu sasaran yang akan dituju. Jack Febrian dalam buku kamus komputer dan teknologi informasi (2007) mengungkapkan bahwa aplikasi adalah program siap pakai, program yang direka untuk melaksanakan suatu fungsi bagi pengguna atau aplikasi yang lain.

Menurut Sutarman dalam buku pengantar teknologi informasi (2009) aplikasi merupakan programprogram yang dibuat oleh suatu perusahaan komputer untuk para pemakai yang beroperasi dalam bidang umum seperti pada pertokoan, komunikasi, penerbangan, perdagangan dan sebagainya.

Hendrayudi dalam buku Visual Basic 2008 untuk berbagai keperluan pemrograman (2009) mendefinisikan bahwa aplikasi adalah kumpulan perintah program yang dibuat untuk melakukan pekerjaan-pekerjaan tertentu (khusus).

Berdasarkan pengertian diatas dapat disimpulkan bahwa pengertian aplikasi adalah program siap pakai yang dibuat untuk para pemakai yang telah dirancang untuk membuat pengguna lebih produktif.

\subsection{Sistem}

Sistem adalah sekumpulan elemen yang saling terkait atau terpadu yang dimaksudkan untuk mencapai suatu kesatuan yang terdiri dari dua atau lebih komponen atau subsistem yang berinteraksi untuk mencapai satu tujuan.

\subsubsection{Karakteristik Sistem}

Suatu sistem mempunyai karakteristik atau sifatsifat tertentu, yaitu mempunyai komponen-komponen (component), batas sistem (boundary), lingkungan luar sistem (environments), penghubung (interface), masukan (input), keluaran (output), pengolah (proccess), dan sasaran (objectives) dan tujuan (goal).

Sebuah sistem terdiri dari berbagai unsur yang saling melengkapi dalam mencapai tujuan dan sasaran. Unsur-unsur yang saling melengkapi tersebut terdapat di dalam sistem yang disebut dengan nama sub sistem. Sub sistem tersebut harus selalu berhubungan dan berinteraksi melalui komunikasi yang relevan sehingga sistem dapat bekerja secara efektif dan efisien.

\subsubsection{Klasifikasi Sistem}

Dari berbagai sudut pandang, sistem dapat diklasifikasikan sebagai berikut :
1. Sistem abstrak dan sistem fisik

Sistem abstrak adalah sistem yang berupa pemikiran atau ide-ide yang tampak secara fisik. Sedangan sistem fisik adalah sistem yang secara fisik dapat dilihat.

2. Sistem tertentu (deterministic) dan tak tentu (probalistic)

Sistem tertentu adalah sistem yang operasinya dapat diprediksi. Sedangkan sistem tak tentu adalah sistem yang kondisi masa depannya tidak dapat diprediksi karena mengandung unsur probabilitas.

3. Sistem tertutup dan sistem terbuka

Sistem tertutup adalah sistem yang tidak berhubungan dengan lingkungan luarnya. Sedangkan sistem terbuka adalah sistem yang berhubungan dengan dan terpengaruh dengan lingkungan luarnya.

4. Sistem alamiah dan sistem buatan

Sistem alamiah adalah sistem yang terjadi melalui proses alam, tidak melalui proses alam. Sedangkan sistem buatan adalah sistem yang dirancang oleh manusia.

\subsection{Manajemen}

Manajemen merupakan proses pengkoordinasian kegiatan-kegiatan pekerjaan sehingga pekerjaan tersebut dapat selesai secara efisien dan efektif dengan dan melalui orang lain. Efisien mengacu pada memperoleh output terbesar dengan input yang terkecil, digambarkan oleh Peter F. Drucker adalah "melakukan pekerjaan dengan benar (doing things right)". Efektivitas mengacu pada menyelesaikan kegiatan-kegiatan sehingga sasaran organisasi dapat tercapai, digambarkan sebagai "mengerjakan pekerjaan yang benar (doing the right things)".

Manejemen adalah suatu bidang pengetahuan yang secara sistematik berusaha memahami mengapa dan bagaimana orang bekerja sama (Luther Gulick). Manajemen adalah seni dalam menyelesaikan sesuatu melalui orang lain (Marry Parket Follet). Manajemen adalah proses perancanaan, pengorganisasian, pengarahan dan pengawasan usaha-usaha para anggota organisasi dan penggunaan sumber daya organisasi lainnya agar mencapai tujuan organisasi yang telah ditetapkan (Stoner).

Dari definisi diatas dapat ditarik kesimpulan bahwa manajemen yaitu koordinasi semua sumber daya melalui proses perencanaan, pengorganisasian, pengarahan dan pengawasan untuk mencapai tujuan yang telah ditetapkan terlebih dahulu. Berdasarkan pengertian

\section{JISICOM (Journal of Information System, Informatics and Computing)} http://journal.stmikjayakarta.ac.id/index.php/jisicom Telp.+62-21-3905050, e-mail:jisicom@stmikjayakarta.ac.id, jisicom2017@gmail.com 
diatas juga dapat disimpulkan bahwa manajemen pada dasarnya sesuatu yang terkait dengan pencapaian tujuan.

Secara umum fungsi manajemen terbagi menjadi 4 macam :

1. Perancanaan (Planning), Proses yang yang menyangkut upaya yang dilakukan untuk mengantisipasi kecenderungan di masa yang akan datang dan penentuan strategi dan taktik yang tepat untuk mewujudkan target dan tujuan organisasi.

2. Pengorganisasian (Organizing), Proses yang menyangkut bagaimana strategi dan taktik yang telah dirumuskan dalam perencanaan didesain dalam sebuah struktur organisasi yang tepat dan tangguh, sistem dan lingkungan organisasi yang kondusif dan dapat memastikan bahwa semua pihak dalam organisasi dapat bekerja secara efektif dan efisien guna pencapaian tujuan organisasi

3. Pengarahan dan pengimplementasi (Directing/Leading), Proses implementasi program dapat dijalankan oleh seluruh pihak dalam organisasi seta proses memotivasi agar semua pihat tersebut dapat menjalankan tanggung jawabnya dengan penuh kesadaran dan produktifitas yang tinggi.

4. Pengawasan dan Pengedalian (Controlling), Proses yang dilakukan untuk memastikan seluruh rangkaian kegiatan yang telah direncanakan, diorganisasikan dan diimplementasikan dapat berjalan sesuai dengan target yang diharapkan sekalipun berbagai perubahan terjadi dalam lingkungan dunia bisnis yang dihadapi.

\subsection{Kepegawaian}

Kepegawaian berasal dari kata pegawai (kamus besar bahasa indonesia), orang pribadi yang bekerja pada pemberi kerja, berdasarkan perjanjian atau kesepakatan kerja baik secara tertulis maupun tidak tertulis untuk melaksanakan suatu pekerjaan dalam jabatan atau kegiatan tertentu dengan memperoleh imbalan yang dibayarkan berdasarkan periode tertentu, penyelesaian pekerjaan atau ketentuan lain yang ditetapkan pemberi kerja, termasuk orang pribadi yang melakukan pekerjaan dalam jabatan negeri.

Sementara untuk kepegawaian sendiri adalah segala sesuatu yang berhubungan dengan pegawai atau sebuah pekerjaan yang mengatur tentang fungsi dan kedudukan seorang pegawai pada sebuah badan, organisasi atau instansi. Kepegawaian sangat berkaitan dengan sumber daya manusia karena kesalahan dalam pengelolaan pegawai pada sebuah instansi sumber daya manusi akan mubazir dan akan mengakibatkan inefisiensi tenaga kerja. Inefisiensi berarti mengeluarkan banyak biaya dan mendapatkan sumber daya yang sedikit. Literatur lainnya mengatakan bahwa mengelola kepegawaian yang baik bisa meningkatkan kinerja pegawai karena akan membangkitkan motivasi kerja.

\subsection{Data}

Data adalah deskripsi tentang benda, kejadian, aktifitas dan transaksi yang tidak mempunyai makna atau tidak berpengaruh langsung kepada pemakai. Data dapat berupa nilai berformat, teks, citra, audio dan video (Kadir, 2014). Data yang berformat adalah data dengan suata format tertentu, misalnya data yang menyatakan tanggal atau jam atau juga menyatakan nilai mata uang.

Teks adalah sederatan huruf, angka dan simbolsimbol khususnya yang kombinasinya tidak tergantung pada masing-masing item secara individual contoh dari teks adalah koran. Citra / gambar adalah data dalam bentuk gambar. Citra dapat berupa grafik, foto, hasil rontgen dan tanda tangan ataupun gambar yang lain.

Audio adalah data dalam bentuk suara. Instrumen musik, suara orang atau suara binatang, gemercik air, detak jantung merupakan contoh data audio. Video menyatakan data dalam bentuk sejumlah gambar yang bergerak dan bisa saja dilengkapi dengan suara. Video dapat digunakan untuk mengabadikan suatu kejadian atau aktivitas.

2.8 Metode Pengembangan Sistem Sekuensia Linear Model Air Terjun (Waterfall Model)

Nama model ini sebenarnya adalah "Linear Sequential Model". Model ini sering disebut dengan "classic life cycle" atau model waterfall. Model ini adalah model yang pertama kali muncul yaitu sekitar tahun 1970 sehingga sering dianggap kuno, tetapi merupakan model yang paling banyak dipakai dalam Software Engineering (SE). Model ini melakukan pendekatan secara sistematis dan urut mulai dari level kebutuhan sistem lalu menuju ke tahap analisis, desain, coding, testing / verification dan maintenance. Disebut dengan waterfall karena tahap demi tahap yang dilalui harus menunggu selesainya tahap sebelumnya dan berjalan berurutan. Secara umum tahapan pada model air terjun dapat dilihat pada gambar berikut :

\section{JISICOM (Journal of Information System, Informatics and Computing)}

http://journal.stmikjayakarta.ac.id/index.php/jisicom Telp.+62-21-3905050, e-mail:jisicom@stmikjayakarta.ac.id, jisicom2017@gmail.com 


\section{Journal of Information System, Informatics and Computing}

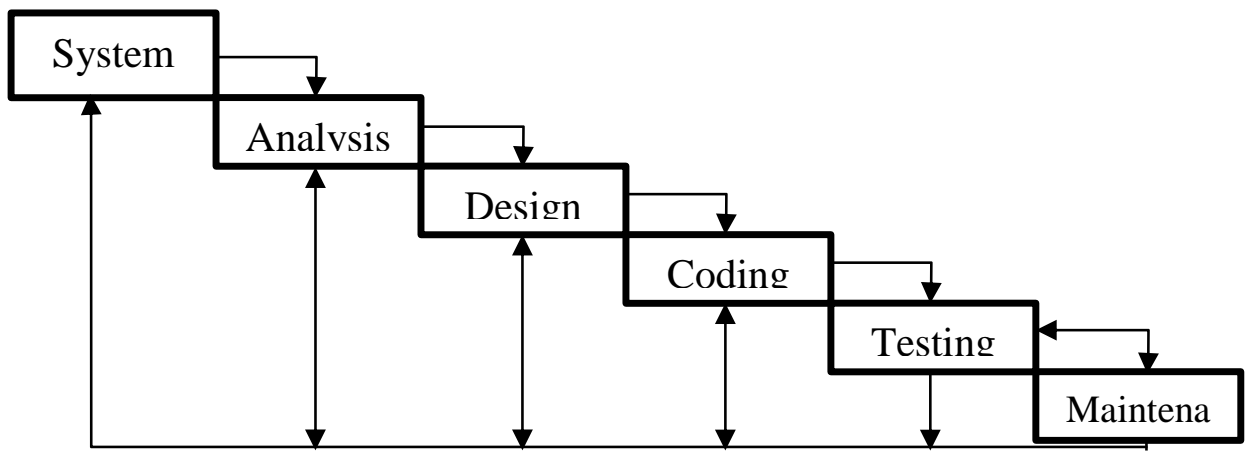

Gambar 1. Waterfall Model

Berikut adalah penejelasan dari tahap-tahap yang dilakukan di dalam model ini menurut pressman :

\section{a. System / Infotmation Engineering and Modeling}

Pemodelan ini diawalai dengan mencari kebutuhan dari keseluruhan sistem yang akan diaplikasikan ke dalam bentuk perangkat lunak. Hal ini sangat penting, mengingat perangkat lunak harus dapat berinteraksi dengan elemen-elemen yang lain seperti perangkat keras, basis data dan sebagainya. Tahap ini sering disebut dengan Project Definition.

\section{b. Software Requirements Analysis}

Proses pencarian kebutuhan diintensifkan dan difokuskan pada perangkat lunak. Untuk mengetahui sifat dari program yang akan dibuat, maka para software engineer harus mengerti tentang domain informasi dari perangkat lunak, misalnya fungsi yang dibutuhkan, user interface dan lainnya. Dari dua aktivitas tersebut (pencarian kebutuhan sistem dan perangkat lunak) harus di dokumentasikan.

\section{c. Design}

Proses ini digunakan untuk mengubah kebutuhankebutuhan diatas menjadi representasi kedalam bentuk "blueprint" perangkat lunak sebelum coding dimulai. Desain harus dapat mengimplementasikan kebutuhan yang telah disebutkan pada tahap sebelumnya. Seperti dua aktivitas sebelumnya, maka proses ini juga harus didokumentasikan sebagai konfigurasi default dari perangkat lunak.

\section{d. Coding}

Untuk dapat dimengerti oleh mesin dalam hal ini adalah komputer, maka desain tadi harus diubah menjadi bentuk yang dimengerti oleh mesin yaitu kedalam bahasa pemograman melalui proses coding. Tahap ini merupakan implementasi dari tahap desain secara teknis nantinya dikerjakan oleh programmer.

\section{e. $\quad$ Testing / Verification}

Sesuatu yang dibuat haruslah di uji cobakan. Demikian juga dengan perangkat lunak. Semua fungsifungsi perangkat lunak harus di uji cobakan, agar perangkat lunak bebas dari error dan hasilnya harus benar-benar sesuai dengan kebutuhan yang sudah didefinisikan sebelumnya.

\section{f. Maintenance}

Pemeliharaan suatu perangkat lunak diperlukan, termasuk di dalamnya adalah pengembangan, karena perangkat lunak yang dibuat tidak selamanya hanya seperti itu. Ketika dijalankan mungkin saja masih ada error kecil yang tidak ditemukan sebelumnya atau ada penembahan fitur-fitur yang belum ada pada perangkat lunak tersebut. Pengembangan diperlukan ketika adanya perubahan dari eksternal perusahaan seperti ada pergantian sistem operasi atau perangkat lainnya.

\section{PEMBAHASAN DAN HASIL \\ 3.1 Basis Data}

Basis data adalah penggunaan bersama dari data yang terhubung secara logis dan deskripsi dari data yang dirancang untuk keperluan informasi. Integrasi logis dari catatan-catatan banyak file disebut sebagai konsep basis data. Tujuan dari konsep basis data yaitu meminimalisir pengulangan data dan mencapai independensi data.

Pengulangan data merupakan duplikasi data, yang berarti data yang sama disimpan dalam beberapa file yang berbeda dan pada tempat yang berbeda. Independensi data adalah kemampuan untuk membuat perubahan dalam struktur data tanpa membuat perubahan program yang memproses data.

Penyusunan basis data digunakan untuk mengatasi masalah-masalah yang timbul pada penyusunan data. Masalah-masalah tersebut adalah sebagai berikut :

1. Redudancy data

\section{JISICOM (Journal of Information System, Informatics and Computing)}

http://journal.stmikjayakarta.ac.id/index.php/jisicom Telp.+62-21-3905050, e-mail:jisicom@stmikjayakarta.ac.id, jisicom2017@gmail.com 
Redudancy data adalah munculnya data-data secara berulang-ulang pada file basis data yang seharusnya tidak diperlukan.

2. Inconsistency data

Inconsistency data terjadi karena kesalahan dalam pemasukan data atau update anomaly, proses update data yang mengakibatkan munculnya data tidak konsisten.

3. Isolation data

Isolation data disebabkan oleh pemakaian beberapa file sehingga program aplikasi yang dipakai tidak mampu mengakses file tertentu dalam basis data tersebut, sehingga perlu mengubah atau menambah seolah-olah ada file yang terpisah atau terisolasi dengan file yang lainnya.

4. Pengaksesan data

Pengaksesan data harus siap diakses oleh siapa saja yang membutuhkan dan mempunyai hak untuk mengaksesnya. Oleh karena itu perlu dibuat suatu program untuk mengetahui penolakan dan penerimaan hak akses, suatu cara untuk mengakses data dikenal dengan DBMS.

5. Masalah keamanan

Masalah keamanan dimana tidak setiap pemakai sistem basis data diperbolehkan mengakses basis data, misalnya data mengenai gaji pegawai hanya boleh dibuka oleh bagian keuangan dan personalia.

6. Masalah integritas (integrity)

Basis data berisi file yang saling berhubungan, masalah utamanya adalah bagaimana kaitan antar file tersebut tersebut terjadi meski diketahui file A berkiatan dengan file $\mathrm{B}$, secara teknis dapat dilakukan dengan adanya sebuat field kunci yang mengaitkan kedua file tersebut.

7. Multiple user

Salah satu alasan basis data dibangun adalah karena nantinya data tersebut digunakan oleh banyak orang baik dalam waktu berbeda atau bersamaan.

\section{Data independent}

Apapun perubahan yang terjadi basis data, semua perintah harus stabil tanpa ada yang diubah.

Konsep dasar dari basis data adalah kumpulan dari catatan-catatan atau potongan dari pengetahuan. Sebuah basis data memiliki penjelasan terstuktur dari jenis fakta yang tersimpan di dalamnya, penjelasan ini disebut skema yang menggambarkan objek yang diwakili suatu basis data dan hubungan antar objek.

Model yang umum digunakan sekarang adalah model realisonal, yang mewakili semua informasi dalam bentuk tabel-tabel yang saling berhubungan dimana setiap tabel terdiri dari baris dan kolom. Dalam model ini, hubungan antar tabel diwakili dengan menggunakan nilai yang sama antar tabel. Model jaringan menggunakan cara yang lebih eksplisit untuk mewakili hubungan antar tabel. Jenis basis data antara lain : basis data hierarkis, basis data jaringan dan basis data relasional.

Dalam terminologi basis data dikenal dengan istilah seperti tabel, baris dan kolom. Tabel (biasa juga disebut relasi) menyatakan bentuk berdimensi dua yang mewakili suatu kelompok data yang sejenis. Sebuah tabel berisi sejumlah kolom yang biasa disebut dengan field dan baris yang biasa disebut dengan record atau tupel. Menurut konsep basis data relasional setiap tabel memiliki kunci primer (primary key) walaupun dalam prakteknya bisa saja tidak memiliki.

Primary key adalah suatu nilai yang bersifat unik (tidak ada nilai kembar) sehingga dapat digunakan untuk membedakan suatu baris dengan baris lainnya dalam sebuah tabel. Dengan kata lain, jika memberikan sebuah nilai berdasarkan primary key maka maksimun hanya ada satu baris memenuhinya. Selain primary key, kunci disi dibagi menjadi candidat key, alternate key, foreign key serta composite key.

\section{Candidate key}

Candidate key adalah satu atau lebih atribut yang mendefinisikan sebuah baris secara unik yang berfungsi sebagan calon primary key serta mempunyai nilai unik pada hampir setiap barisnya. Dapat dikatan candidate key merupakan kunci yang belum menjadi kunci primer tabel.

2. Alternate key

Alternate key adalah candidat key yang tidak dipilih untuk mendefinisikan sebuat baris secara unik, tetapi perlu dicatat meskipun tidak menjadi alternate key disebuah tabel akan tetapi tidak menutup kemungkinan bisa menjadi primari key di tabel lainnya.

\section{Foreign key}

Foreign key adalah sembarang kolom yang menunjukan ke kunci primer (primary key) milik tabel lain.

4. Composite key

Composite key adalah kunci primer (primary key) yang tidak terbentuk oleh sebuah kolom melainkan tersusun atas beberapa kolom.

\subsection{Diagram Alir (Flowchart)}

Flowchart digunakan untuk menggambarkan algoritma dari program atau aplikasi yang akan dibuat nantinya agar tidak terjadi masalah pada program atau aplikasi tersebut.

Kusrini (2007) mengungkapkan "Flowchart adalah bagan (chart) yang menunjukan aliran (flow) di dalam program atau prosedur sistem secara logika, digunakan terutama sebagai alat bantu komunikasi dan untuk dokumentasi". Suarga (2006) mengungkapkan “Flowchart

\section{JISICOM (Journal of Information System, Informatics and Computing)}

http://journal.stmikjayakarta.ac.id/index.php/jisicom Telp.+62-21-3905050, e-mail:jisicom@stmikjayakarta.ac.id, jisicom2017@gmail.com 
adalah untaian simbol gambar (chart) yang menunjukan aliran (flow) dari proses terhadap data".

Berdasarkan pendapat di atas, dapat disimpulkan bahwa flowchart adalah suatu alur program yang menggambarkan atau mempresentasikan suatu algoritma yang dibuat dari pembuka, isi, sampai keluar program untuk menyelesaikan suatu permasalahan.

\subsection{ERD (Entity Relationship Diagram)}

ERD adalah model data untuk menggambarkan hubungan antara satu entitas denga entitas lain yang mempunyai relasi (hubungan) dengan batasan tertentu. Hubungan antara entitas akan menyangkut dua komponen yang menyatakan jalinan ikatan yang terjadi, yaitu derajat hubungan dan partisipasi hubungan. Derajat hubungan menyatakan jumlah anggota entitas yang terlibat didalam ikatan yang terjadi dalam membentuk hubungan. Derajat hubungan pada relationship type, batasan structural cardinality ratio memiliki jenis :

1. $1: 1$ (One to One Relationship), hubungan antara file pertama dengan file kedua adalah satu berbanding satu. Derajat hubungan antar entitas 1:1 terjadi bilai tiap anggota entitas A hanya boleh berpasangan dengan satu anggota dari entitas B. Hubungan ini dapat digambarkan dengan tanda lingkaran untuk menunjukkan tabel dan relasi antar keduanya diwakilkan dengan tanda panah tunggal.

2. 1:M (One to Many Relatioship), hubungan antar file pertama dengan file kedua adalah satu berbanding banyak atau dapat pula dibalik menjadi banyak berbanding satu. Derajat hubungan ini terjadi bila tiap anggota entitas A boleh berpasangn dengan lebih dari satu anggota B. Sebalikanya tiap anggota entitas B hanya boleh berpasangan dengan satu anggota entitas A. Hubungan ini dapat digambarkan dengan lingkaran untuk menunjukan tabel dan relasi antar keduanya diwakilkan dengan tanda panah ganda untuk menunjukan hubungan banyak tersebut.

3. M:M (Many to Many Relationship), hubungan antar satu atribut dengan atribut yang lain dalam satu file yang sama mempunyai hubungan banyak lawan banyak. Derajat hubungai ini terjadi bila tiap anggota entitas $\mathrm{A}$ boleh berpasangan dengan lebih dari satu anggota B, begitu juga sebaliknya.

\subsection{DFD (Data Flow Diagram)}

DFD (Data Flow Diagram) merupakan diagram yang menggunakan notasi-notasi untuk menggambarkan arus data sistem secara logika. DFD menggambarkan komponen-komponen sebuah sistem. Keuntungan menggunakan DFD adalah memudahkan pemakai yang kurang menguasai komputer untuk mengerti sistem yang akan dikembangkan. Tahapan penulisan DFD untuk membuat desain sistem dilakukan dengan :

1. Mempelajari operasi dan proses yang telah ada di dalam sistem. Proses sistem ditinjau dari kesatuan luar dan kesatuan dalam unsur-unsur pembentuknya.

2. Melakukan identifikasi dari prosedur data proses dalam suatu transaksi.

3. Mengikuti aliran data yang terjadi dalam transaksi pada sistem.

4. Mengambarkan ke dalam diagram konteks yang berisi proses sistem yang diperlajari secara menyeluruh. Kemudian proses diperinci dengan overview diagram (level-level yang lebih memperinci program). Jadi secara bertahap pada kondisi ini menambahkan detail proses pada level yang lebih rendah.

Level 0 : Proses Global

Level 1, 2, 3 .... : Gambaran ringkasan, detail proses dan kontrol

DFD merupakan dokumentasi grafik yang menggunakan simbol penomoran di dalam mengilustrasikan arus data yang saling berhubungan diantara pemrosesan data untuk diubah menjadi informasi. Dengan demikian proses di dalam DFD adalah ditekankan pada informasi data.

\subsection{Web Browser}

Web Browser dalam bahasa Indonesia Penjelajah web atau Peramban web adalah perangkat lunak yang berfungsi untuk menerima dan menyajikan sumber informasi di Internet. Sebuah sumber informasi diidentifikasi dengan pengidentifikasi sumber seragam yang dapat berupa halaman web, gambar, video, atau jenis konten lainnya.

Meskipun penjelajah web terutama ditujukan untuk mengakses Internet, sebuah penjelajah juga dapat digunakan untuk mengakses informasi yang disediakan oleh server web dalam jaringan pribadi atau berkas pada sistem berkas. Beberapa penjelajah web yang populer adalah Google Chrome, Firefox, Internet Explorer, Opera, dan Safar

\subsection{Web Server}

Server web atau peladen web dapat merujuk baik pada perangkat keras ataupun perangkat lunak yang menyediakan layanan akses kepada pengguna melalui protokol komunikasi HTTP atau HTTPS atas berkasberkas yang terdapat pada suatu situs web dalam layanan ke pengguna dengan menggunakan aplikasi tertentu seperti peramban web.

Penggunaan paling umum server web adalah untuk menempatkan situs web, namun pada praktek

\section{JISICOM (Journal of Information System, Informatics and Computing)}

http://journal.stmikjayakarta.ac.id/index.php/jisicom Telp.+62-21-3905050, e-mail:jisicom@stmikjayakarta.ac.id, jisicom2017@gmail.com 
penggunaannya diperluas sebagai tempat peyimpanan data ataupun untuk menjalankan sejumlah aplikasi kelas bisnis.

Fungsi utama sebuah server web adalah untuk mentransfer berkas atas permintaan pengguna melalui protokol komunikasi yang telah ditentukan. Disebabkan sebuah halaman web dapat terdiri atas berkas teks, gambar, video, dan lainnya pemanfaatan server web berfungsi pula untuk mentransfer seluruh aspek pemberkasan dalam sebuah halaman web yang terkait : termasuk di dalamnya teks, gambar, video, atau lainnya.

Pengguna, biasanya melalui aplikasi pengguna seperti peramban web, meminta layanan atas berkas ataupun halaman web yang terdapat pada sebuah server web, kemudian server sebagai manajer layanan tersebut akan merespon balik dengan mengirimkan halaman dan berkas-berkas pendukung yang dibutuhkan, atau menolak permintaan tersebut jika halaman yang diminta tidak tersedia. saat ini umumnya server web telah dilengkapi pula dengan mesin penerjemah bahasa skrip yang memungkinkan server web menyediakan layanan situs web dinamis dengan memanfaatkan pustaka tambahan seperti PHP, ASP.

Pemanfaatan server web saat ini tidak terbatas hanya untuk publikasi situs web dalam World Wide Web, pada praktiknya server web banyak pula digunakan dalam perangkat-perangkat keras lain seperti printer, router, kamera web yang menyediakan akses layanan http dalam jaringan lokal yang ditujukan untuk menyediakan perangkat manajemen serta mempermudah peninjauan atas perangkat keras tersebut.

\subsection{XAMPP}

XAMPP adalah perangkat lunak bebas, yang mendukung banyak sistem operasi, merupakan kompilasi dari beberapa program. Fungsinya adalah sebagai server yang berdiri sendiri (localhost), yang terdiri atas program Apache HTTP Server, MySQL database, dan penerjemah bahasa yang ditulis dengan bahasa pemrograman PHP dan Perl. Nama XAMPP merupakan singkatan dari X (empat sistem operasi apapun), Apache, MySQL, PHP dan Perl. Program ini tersedia dalam GNU General Public License dan bebas, merupakan web server yang mudah digunakan yang dapat melayani tampilan halaman web yang dinamis. Untuk mendapatkanya dapat mendownload langsung dari web resminya.

\subsection{MySQL}

SQL (Structured Query Language) merupakan sebuah bahasa relational yang berisi pernyataan yang digunakan untuk memasukkan, mengubah, menghapus, memilih dan melindungi data. SQL bukan database aplikasi, tetapi lebih berarti dengan suatu bahasa yang digunakan untuk mengajukan pertanyaan ke dalam database berupa pengguna SQL.

Database sistem yang memiliki konsep sama dengan SQL, adalah Postgres dan MySQL, dimana database tersebut bisa didapatkan gratis atau dengan harga yang murah. MySQL adalah server multithreaded, sehingga sangat memungkinkan daemon untuk menghandle permintaan layanan secara simultan. Model koneksi dengan protokol TCP-IP membuat akses ke server database lebih cepat jika dibandingkan dngan menggunakan mapping drive.

\subsection{WWW (World Wide Web)}

Web atau World Wide Web dalam Bahasa Indonesia Jaringan Jagat Jembar (JJJ) adalah salat satu fasilitas yang disediakan di internet. Web merupakan dunia maya di internet yang terdapat ribuan informasi tentang segala hal dan dikemas dalam bentuk dokumen hypertext. Hypertext merupakan konsep dasar dari world wide web. Dokumen hypertext adalah salah satu dokumen yang memungkinkan untuk menjelajahi dari suatu halaman web ke halaman web yang lainnya dengan menggunakan suatu link.

Web bekerja dalam jaringan komputer yang memanfaatkan teknologi Hypertext Transfer Protocol (HTTP), Uniform Resource Locator (URL), Protocol Transfer dan Domain Name Server (DNS).

Hypertext Transfer Protocol (HTTP) adalah suat protokol yang digunakan oleh web. HTTP mendefinisikan bagaimana suatu pesan bisa diformat dan dikirimkan dari server ke client. Uniform Resource Locator (URL) adalah rangkaian karakter menurut suatu format standar tertentu yang digunakan untuk menunjukan alamat suatu sumber seperti dokumen dan gambar di internet. Domain Name Server (DNS) adalah sistem yang menyimpan informasi tentang nama host maupun nama domain dalam bentuk basis data tersebut (distributed database) di dalam jaringan komputer.

\subsection{HTTP (Hyper Text Transfer Protocol)}

HTTP adalah protokol yang menetukan aturan yang perlu diikuti oleh web browser dalam meminta atau mengambil suatu dokumen dan oleh web server dalam menyediakan dokumen yang diminta oleh web browser. Protokol ini di desain untuk mentransfer berkas yang berisi hypertext seperti berkas yang berisi HTML yang digunakan di World Wide Web. Server dari WWW biasanya dikenal dengan nama HTTPD.

\subsection{HTML (Hyper Text Markup Language)}

\section{JISICOM (Journal of Information System, Informatics and Computing)}

http://journal.stmikjayakarta.ac.id/index.php/jisicom Telp.+62-21-3905050, e-mail: jisicom@stmikjayakarta.ac.id, jisicom2017@gmail.com 
Hyper Text Markup Language adalah salah satu format yang digunakan untuk menulis halaman web, HTML ini berjalan di web browser dan memiliki fungsi untuk melakukan pemrograman aplikasi di atas web. HTML merupakan pengembangan dari standar pemformatan dokumen teks, yaitu standar Generalized Merkup Language. HTML sebenarnya adalah dokumen ASCII atau teks biasa, yang dirancang untuk tidak tergantung pada suatu sistem operasi tertentu.

\subsection{PHP (PHP : Hypertext Preprocessor)}

PHP (Perl Hypertext Preprocessor) merupakan bahasa berbentuk skrip yang di tempatkan dalam server dan di proses di server. Selain itu juga PHP merupakan salah satu dari sekian banyak bahasa pemrograman HTML (Hypertext Markup Language). Dibuat oleh Rasmus Lerdorf diawali dengan membuatnya sebagai personal project dan disempurnakan oleh group six of developers dan lahir kembali dengan nama PHP.

Secara khusus, PHP dirancang untuk membentuk web dinamis. Artinya, PHP dapat membentuk suatu tampilan berdasarkan permintaan. PHP memiliki kemampuan yang baik dalam hal perhitungan matematika, dalam hal informasi jaringan e-mail dan regular expression. Selain itu PHP juga mampu sebagai interface dengan database secara baik, support dengan bermacam-macam database server seperti MySQL, ORACLE, Sysbase.

PHP dapat berjalan dengan web server yang berbeda dan dalam sistem operasi yang berbeda pula. PHP dapat berjalan di sistem operasi UNIX, Windows97, WindowsNT. PHP adalah bahasa scripting yang menyatu dengan HTML untuk membuat halaman web yang dinamis dan dijalankan pada server side. Artinya semua sintaks yang kita berikan akan sepenuhnya dijalankan pada server tetapi disertakan pada dokumen HTML sedangkan yang dikirim ke browser hanya hasilnya saja.

\subsection{JavaScript}

Javascripts adalah nama implementasi Netscape Communications Corporation untuk ECMA Script Standar, suatu bahasa skrip yang didasarkan pada konsep pemrograman berbasis prototipe (www.wikipedia.org). Bahasa ini terkenal karena penggunaannya di situs web pada sisi klien dan juga digunakan untuk menyediakan akses skrip untuk objek yang dibenamkan (embedded) di aplikasi lain. Walaupun memiliki nama serupa, namun Javascript hanya sedikit sekali berhubungan dengan bahasa pemrograman Java. Secara semantik, Javascript memiliki lebih banyak kesamaan/kemiripan dengan bahasa pemrograman Self.
Javascript digunakan untuk mengakses sebuah objek program bersama aplikasi-aplikasi lainnya. dan utamanya digunakan pada form klien disamping Javascript sebagai pengembangan untuk website-website. Javascript mempunyai karakteristik yang dinamis, kuat, menjadi dasar bahasa untuk prototipe dengan fungsifungsi kelas utama. Javascript di desain seperti Java tetapi tetap mudah dalam penanganannya

\subsection{CSS (Cascading Style Sheet)}

Cascading Style Sheet (CSS) merupakan aturan untuk mengatur beberapa komponen dalam sebuah web sehingga akan lebih terstruktur dan seragam. CSS bukan merupakan bahasa pemograman. Sama halnya styles dalam aplikasi pengolahan kata seperti Microsoft Word yang dapat mengatur beberapa style, misalnya heading, subbab, bodytext, footer, images, dan style lainnya untuk dapat digunakan bersama-sama dalam beberapa berkas. Pada umumnya CSS dipakai untuk memformat tampilan halaman web yang dibuat dengan bahasa HTML dan XHTML.

CSS dapat mengendalikan ukuran gambar, warna bagian tubuh pada teks, warna tabel, ukuran border, warna border, warna hyperlink, warna mouse over, spasi antar paragraf, spasi antar teks, margin kiri, kanan, atas, bawah, dan parameter lainnya. CSS adalah bahasa style sheet yang digunakan untuk mengatur tampilan dokumen. Dengan adanya CSS memungkinkan kita untuk menampilkan halaman yang sama dengan format yang berbeda.

\subsection{Sidik Jari}

Sidik jari dalam bahasa inggris fingerprint adalah hasil reproduksi tapak jari baik yang sengaja diambil, dicapkan dengan tinta, maupun bekas yang ditinggalkan pada benda karena pernah tersentuh kulit telapak tangan atau kaki. Kulit telapak adalah kulit pada bagian telapak tangan mulai dari pangkal pergelangan sampai kesemua ujung jari, dan kulit bagian dari telapak kaki mulai dari tumit sampai ke ujung jari yang mana pada daerah tersebut terdapat garis halus menonjol yang keluar satu sama lain yang dipisahkan oleh celah atau alur yang membentuk struktur tertentu.

Teknologi sidik jari yang memiliki kelebihan yang tidak dapat dihilangkan, dipindahkan dari satu orang ke orang yang lainnya, juga sulit untuk dipalsukan dan ditiru. Teknologi sidik jari ini cukup popular dan banyak digunakan oleh perusahaan di berbagai bidang industri. Adapun keunggulan dari teknologi sidik jari / fingerprint ini yaitu:

\section{JISICOM (Journal of Information System, Informatics and Computing)}

http://journal.stmikjayakarta.ac.id/index.php/jisicom Telp.+62-21-3905050, e-mail:jisicom@stmikjayakarta.ac.id, jisicom2017@gmail.com 
a. Tidak memungkinkannya manipulasi presensi. Sidik jari tidak dapat dititipkan seperti kartu absen manual.

b. Penggunaan sidik jari tidak memerlukan kartu untuk melakukan presensi, jadi bisa meminimalisir alasan kehilangan kartu.

c. Pencatatan data yang sangat akurat karena menggunakan komputer.

d. Sistem yang sudah otomatis dan selalu langsung terhubung dengan system kepegawaian dapat mempersingkat waktu dan tenaga.

\subsection{Pemindai Sidik Jari}

Pemindai sidik jari adalah sebuah perangkat elektronik yang digunakan untuk menangkap gambar digital dari pola sidik jari. Gambar tersebut disebut pemindaian hidup. Pemindaian hidup adalah pemrosesan digital untuk membuat sebuah template biometrik yang disimpan dan digunakan untuk pencocokan. Ini merupakan ikhtisar dari beberapa sidik jari yang lebih umum digunakan sensor teknologi.

\subsection{Bootstrap}

Bootstrap adalah sebuah library framework CSS yang di buat khusus untuk bagian pengembangan frontend website. Bootstrap merupakan salah satu framework HTML, CSS dan javascript yang paling populer di kalangan web developer. Pada saat ini hampir semua web developer telah menggunakan bootstrap untuk membuat tampilan front-end menjadi lebih mudah dan sangat cepat. Karena anda hanya perlu menambahkan class-class tertentu untuk misalnya membuat tombol, grid, navigasi dan lainnya.

Bootstrap merupakan framework untuk membangun desain web secara responsif. Artinya, tampilan web yang dibuat oleh bootstrap akan menyesuaikan ukuran layar dari browser yang kita gunakan baik di desktop, tablet ataupun mobile device. Fitur ini bisa diaktifkan ataupun dinon-aktifkan sesuai dengan keinginan kita sendiri. Sehingga, kita bisa membuat web untuk tampilan desktop saja dan apabila dirender oleh mobile browser maka tampilan dari web yang kita buat tidak bisa beradaptasi sesuai layar. Dengan bootstrap kita juga bisa membangun web dinamis ataupun statis.

Bootstrap telah menyediakan kumpulan komponen class interface dasar yang telah di rancang sedemikian rupa untuk menciptakan tampilan yang menarik, bersih dan ringan. selain komponen class interface, bootstrap juga memiliki fitur grid yang berfungsi untuk mengatur layout pada halaman website yang bisa digunakan dengan sangat mudah dan cepat. dengan menggunakan bootstrap kita juga di beri keleluasaan dalam mengembangkan tampilan website yang menggunakan bootstrap yaitu dengan cara mengubah tampilan bootstrap dengan menambahkan class dan CSS sendiri.

\subsection{Notepad++}

Notepad++ (Notepad plus plus) adalah program aplikasi pengembang yang berguna untuk mengedit teks dan skrip kode pemrograman. Perangkat lunak komputer ini memiliki kelebihan pada peningkatan kemampuan sebuah program text editor, lebih dari sekedar program Notepad bawaan Windows. Notepad++ bisa mengenal tag dan kode dalam berbagai bahasa pemrograman. Fitur pencarian tingkat lanjut dan pengeditan teks yang tersedia juga cukup ampuh, sangat membantu tugas seorang programmer atau developer dalam menyelesaikan skrip kode programnya.

Program Notepad++ banyak diaplikasikan dan digunakan oleh kalangan pengguna komputer di bidang pemrograman aplikasi desktop dan web. Notepad++ merupakan software gratis (opensource). Notepad++ dapat dijalankan di sistem Windows, Linux, Mac. Untuk menginstall versi terbaru program ini, komputer Windows Anda cukup memiliki kapasitas kosong harddisk minimal $12 \mathrm{MB}$.

\subsection{Analisis Proses Model Metode}

Metode merupakan cara untuk mengungkapkan kebenaran yang objektif. Kebenaran tersebut merupakan tujuan, sementara metode itu adalah cara. Penggunaan metode dimaksudkan agar kebenaran yang diungkapkan benar-benar berdasarkan bukti ilmiah yang kuat. Metode dapat diartikan pula sebagai prosedur atau rangkaian cara yang secara sistematis dalam menggali kebenaran ilmiah. Sedangkan penelitian dapat diartikan sebagai pekerjaan ilmiah yang harus dilakukan secara sistematis, teratur dan tertib, baik mengenai prosedurnya maupun dalam proses berfikir tentang materinya oleh Nawawi et all. ( 2011).

Dalam penelitian terdapat berbagai teknik pengumpulan data atau informasi penelitian. Dari keberagaman teknik pengumpulan data, terdapat kesamaan yaitu untuk mendapatkan atau mengumpulkan data dan informasi yang dapat menjelaskan dan menjawab permasalahan penelitian yang bersangkutan secara objektif.

Metode yang digunakan dalam penelitian ini adalah metode deskriptif. Metode deskriptif adalah suatu metode dalam meneliti sekelompok manusia, suatu objek, suatu metode yang mengemukakan masalah dengan mengumpulkan data-data yang disajikan untuk menggambarkan karakteristik suatu keadaan atau objek

\section{JISICOM (Journal of Information System, Informatics and Computing)}

http://journal.stmikjayakarta.ac.id/index.php/jisicom Telp.+62-21-3905050, e-mail:jisicom@stmikjayakarta.ac.id, jisicom2017@gmail.com 


\section{Journal of Information System, Informatics and Computing}

penelitian dan mengambil kesimpulan yang akan dilakukan.

Seperti yang dikembangkan oleh Sugiyono (2011) "Penelitian deskriptif adalah sebuah penelitian yang bertujuan untuk memberikan atau menjabarkan suatu keadaan atau fenomena yang terjadi saat ini dengan menggunakan prosedur ilmiah untuk menjawab masalah secara aktual". Sedangkan menurut Sukmadinata menyatakan bahwa metode penelitian deskriptif adalah semua metode yang berusaha mendeskripsikan, menginterpretasikan sesuatu, proses yang sedang berlangsung, akibat atau efek yang terjadi atau tentang kecenderungan yang sedang berlangsung.

Dari kedua pengertian tersebut dapat dikatakan bahwa metode penelitian deskriptif adalah sebuah metode yang digunakan untuk mendeskripsikan, menginterpretasikan sesuatu fenomena, misalnya atau hubungan yang ada, pendapat yang berkembang dengan menggunakan prosedur ilmiah untuk menjawab masalah secara aktual. Dengan demikian, penulis beranggapan bahwa metode penelitian deskriptif sesuai dengan penelitian yang dilaksanakan oleh penulis. Karena dalam penelitian ini, penulis berusaha mendeskripsikan sebuah masalah atau fenomena yang terdapat dan terjadi pada PT. Bintang Komunikasi Utama. Objek penelitian merupakan sesuatu yang menjadi perhatian dalam suatu penelitian, objek penelitian ini menjadi sasaran dalam penelitian untuk mendapat jawaban ataupun solusi dari permasalahan yang terjadi.

Sugiyono (2011), objek penelitian adalah sasaran ilmiah untuk mendapatkan data dengan tujuan dan kegunaan tertentu tentang sesuatu hal objektif, valid, dan reliable tentang sesuatu hal (variabel tertentu)".

Dari penjelasan diatas dapat dipahami bahwa objek penelitian digunakan untuk mendapatkan data sesuai tujuan dan kegunaan tertentu yang objektif, valid dan realible. Objek penelitian dalam penelitian ini adalah mengenai manajemen kepegawaian yang terjadi pada PT. Bintang Komunikasi Utama.



Gambar 3.1 Peta Lokasi PT. Bintang Komunikasi Utama

PT. Bintang Komunikasi Utama menawarkan layanan jasa berupa survei, pemasangan, perbaikan, pemeliharaan dan pengadaan perangkat serta layanan Network VSAT $I P$ kepada perusahaan pengguna jasa telekomunikasi.

Saat ini PT. Bintang Komunikasi Utama didukung oleh 70 Orang tenaga profesional yang terbagi dalam unit kerja Workshop, Repair Center, Information Techonology, Warehouse, Creative Team, dan dilengkapi dengan aplikasi serta alat ukur yang memadai untuk bidang satelit, radio link dan cellular.

\subsubsection{Software Requirements Analysis}

Pada tahap kedua, penulis melakukan analisis dengan proses pencarian kebutuhan yang diintensifkan dan difokuskan pada perangkat lunaknya. Dari analisis ini, penulis dapat mengelompokan kebutuhan menjadi tiga bagian. Ketiga kelompok tersebut adalah sebagai berikut :

a. Kebutuhan bisnis

Dari segi kebutuhan bisnis, program dibuat untuk memperbaharui sistem yang lama karena adanya penambahan fitur baru. Tujuan utama pembuatan program ini agar dapat menyajikan

\section{JISICOM (Journal of Information System, Informatics and Computing)}

http://journal.stmikjayakarta.ac.id/index.php/jisicom Telp.+62-21-3905050, e-mail:jisicom@stmikjayakarta.ac.id, jisicom2017@gmail.com 
laporan mengenai data kepegawaian yang bisa disesuaikan dengan kebutuhan fungsional. Laporan yang dihasilkan berupa tabel dan grafik yang menunjukan tingkat kehadiran atau kedatangan pegawai di kantor.

b. Kebutuhan data atau informasi

Seperti yang telah dijelaskan pada metode pengumpalan data, kebutuhan akan data dan informasi sangatlah penting bagi pembuatan sistem kepegawaian. Banyak data dan informasi yang dapat dijadikan sebagai bahan acuan dalam pembuatan sistem supaya dalam pembuatannya tidak melenceng dari apa yang ditarget oleh perusahaan. Data dan informasi disusun dan di kelompokan berdasarkan kebutuhan yang telah ditentukan sebelumnya.

c. Kebutuhan Teknologi informasi

1. Perangkat Keras

Spesifikasi minimum perangkat keras (komputer) yang dibutuhkan dalam pengembangan aplikasi ini adalah sebagai berikut :

a. Perangkat Personal Komputer

b. Prosesor Intel Pentium 4 atau AMD Athlon $1 \mathrm{GHz}$ 32-bit atau 64-bit atau lebih tinggi.

c. RAM (Random Access Memory) $1 \mathrm{~GB}$

d. Harddisk Drive 40 GB

e. Pemindai sidik jari

2. Perangkat Lunak

Untuk perangkat lunak sendiri yang harus ada adalah sebagai berikut :

a. OS (Operating System) Windows $\mathrm{XP}$, Windows 7 atau linux.

b. XAMPP, LAMPP atau yang lain untuk aplikasi web server.

c. Notepad, Notepad++ atau yang lain untuk text editor.

d. Firefox, Chrome atau yang lain sebagai web browser.

3. Jaringan

Dalam implementasinya nanti sistem

aplikasi hanya beroperasi dilingkungan kantor saja atau dalam jaringan intranet, maka dari itu tidak diperlukan jaringan atau pengalamat IP tertentu yang khusus dibuat untuk menjalankan sistem. Dalam penggunaan IP Address sendiri hanya dibutuhkan 2 buah IP, satu (1) IP untuk komputer / server dan satu (1) IP yang lainnya mesin pemindai sidik jari. Pemberian IP sendiri mengikuti jaringan yang sudah ada.

\subsubsection{Analisis Kebutuhan dan Arsitektu Sistem}

Analisis kebutuhan digunakan untuk mengidentifikasi terhadap kebutuhan sistem. Kebutuhan sistem meliputi analisis kebutuhan user, kebutuhan admin dan analisis kebutuhan sistem manajemen kepegawaian pada PT. Bintang Komunikasi Utama. Sistem akan menampilkan informasi kepada user dengan memproses data yang telah tersimpan di database.

\section{Kebutuhan User}

Kebutuhan user meliputi apa saja yang dibutuhkan oleh user pada sistem manajemen kepegawaian :

a. Data kepegawaian

b. Laporan kehadiran pegawai

c. Form pengajuan cuti pegawai

d. Form pengajuan keterangan absensi pegawai

\section{Kebutuhan admin}

Kebutuhan admin pada sistem ini meliputi apa saja yang dibutuhkan admin admin pada sistem ini :

a. Melakukan proses login terhadap sistem

b. Mengolah data kepegawaian

c. Mengolah laporan pegawai

d. Mengolah data cuti pegawai

e. Mengolah data keterangan absensi pegawai

\section{Arsitektur Sistem}

Sistem ini dibangun untuk memberikan informasi kepada pegawai yang ada di PT. Bintang Komunikasi Utama melalui jaringan intranet. 


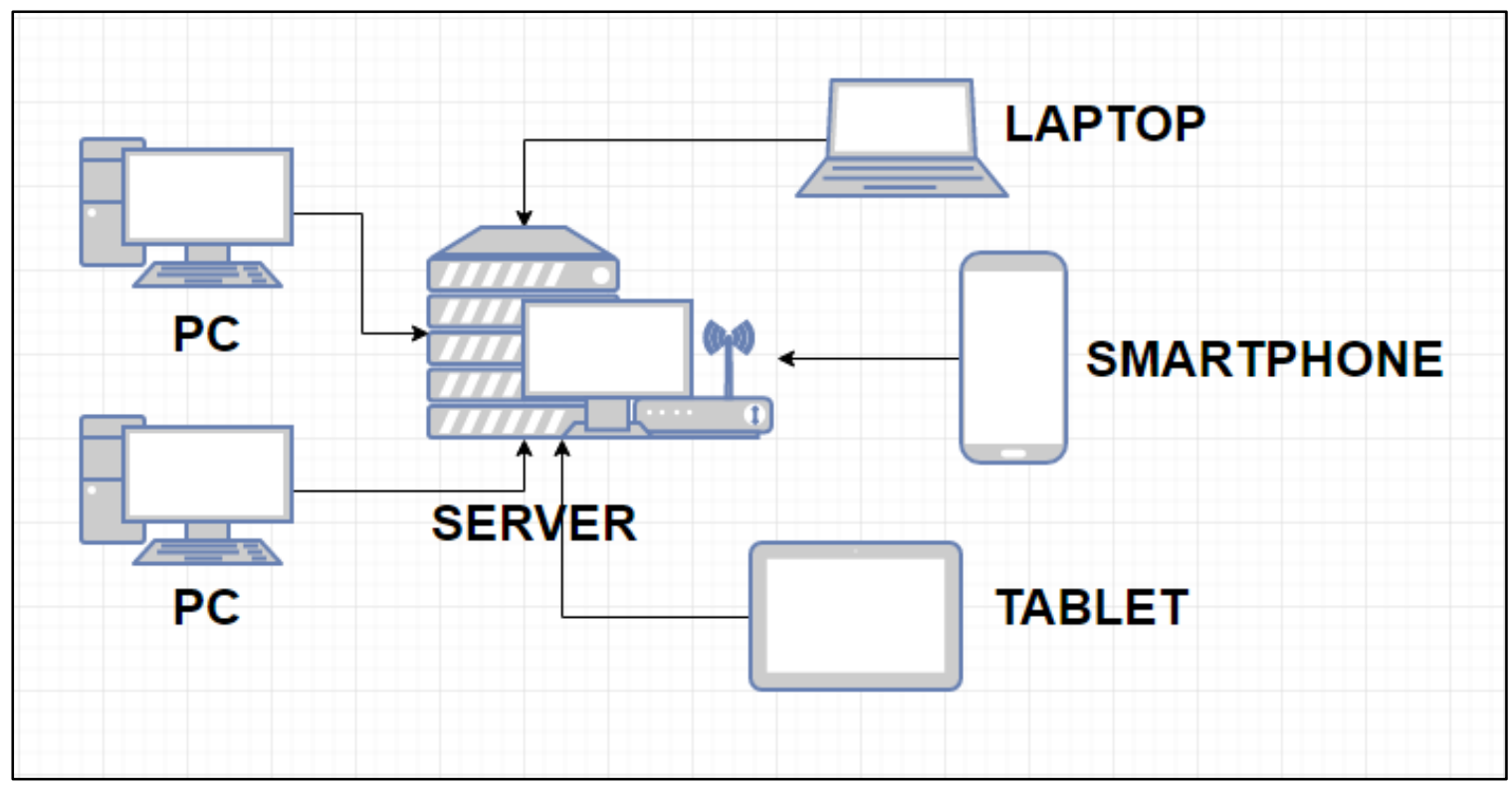

Gambar 3.2 Arsitektur Sistem

\subsubsection{Desain Sistem}

Tujuan utama dari perancangan sistem adalah memberikan gambaran perancangan sistem yang akan dibangun atau dikembangkan, serta untuk memahami alur informasi dan proses dalam sistem. Berikut telah ditentukan tahapan-tahapan atau langkah-langkah yang akan dilakukan dalam perancangan sistem :
a. Rancangan Proses
b. Rancangan Basis Data
c. Rancangan User Interface 


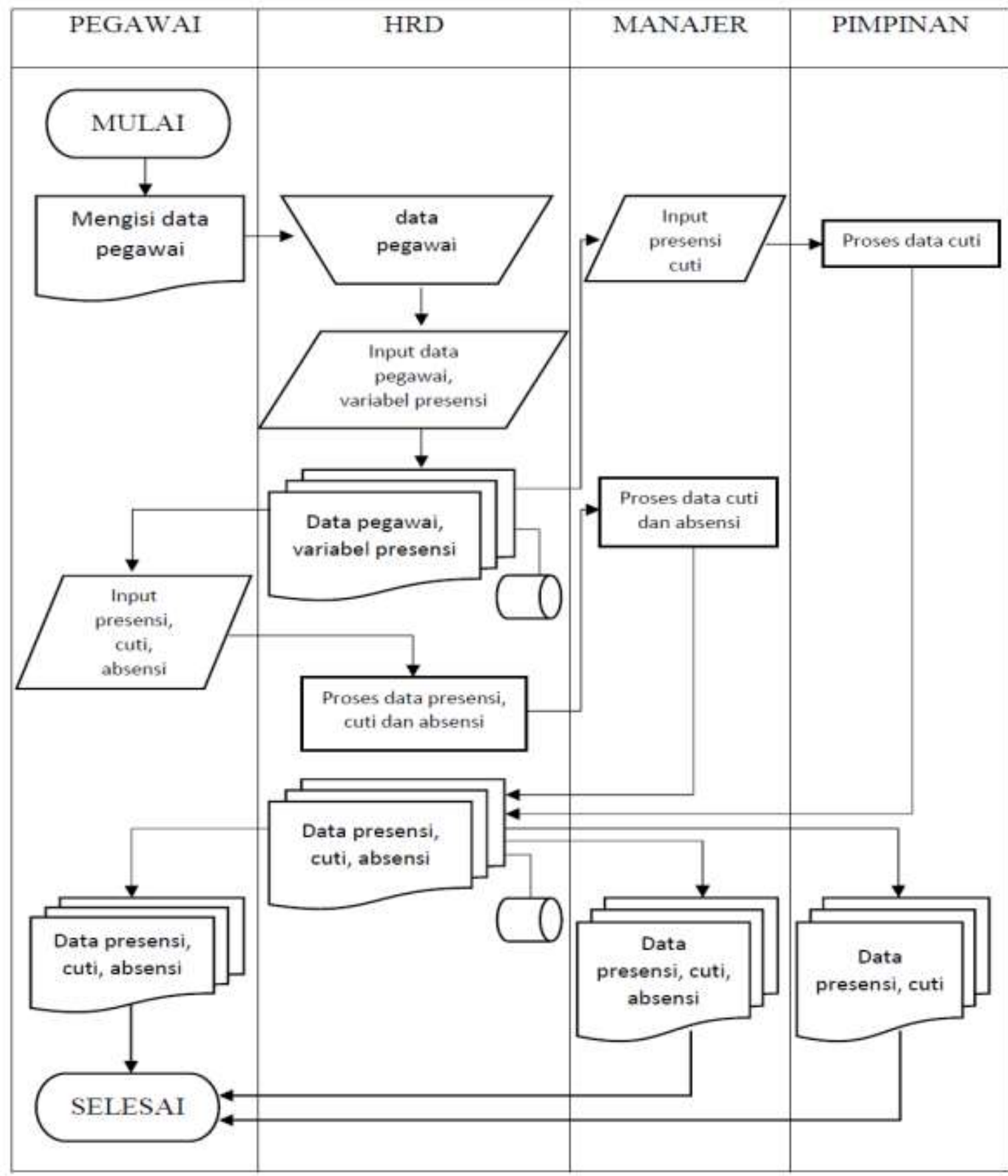

Gambar 3..3 Flow Of Document

JISICOM (Journal of Information System, Informatics and Computing)

http://journal.stmikjayakarta.ac.id/index.php/jisicom Telp.+62-21-3905050, e-mail:jisicom@stmikjayakarta.ac.id, jisicom2017@gmail.com 
Keterangan gambar 3.3 Flow of Document

a. Pegawai mengisi data pegawai yang diminta oleh pihak HRD.

b. Setelah data diserahkan oleh pegawai ke pihak HRD, selanjutnya data tersebut diperiksa apakah data sudah lengkap sesuai dengan yang dibutuhkan.

c. Setelah data diperiksa, data diinput ke database.

d. Pegawai melakukan check-in setiap masuk kerja dan check-out pada saat pulang

e. Pegawai melakukan pengajuan form cuti dan pengajuan keterangan absensi ketika pegawai tidak masuk kerja

f. Pengajuan cuti dan keterangan absensi diajukan kepada pimpinan unit kerja g. Setelah form pengajuan di setujui oleh pimpinan unit kerja, diteruskan oleh bagian HRD untuk dijadikan arsip dalam cuti pegawai

h. Data presensi, data cuti dan data absensi masuk secara otomatis kedalam laporan kehadiran pegawai setiap bulannya.

\subsubsection{Rancangan Proses}

DFD (Data Flow Diagaram) adalah model untuk menggambarkan asal dan tujuan penyimpanan data, proses akan menghasilkan data dan interaksi antar data yang tersimpan dalam proses tersebut. Data perancangan aliran data menggunakan DFD (Data Flow Diagram) yang terbagi menjadi beberapa level Yaitu DFD level 0, DFD level 1, DFD level 2.

\section{DFD Level 0 (Diagram Konteks)}

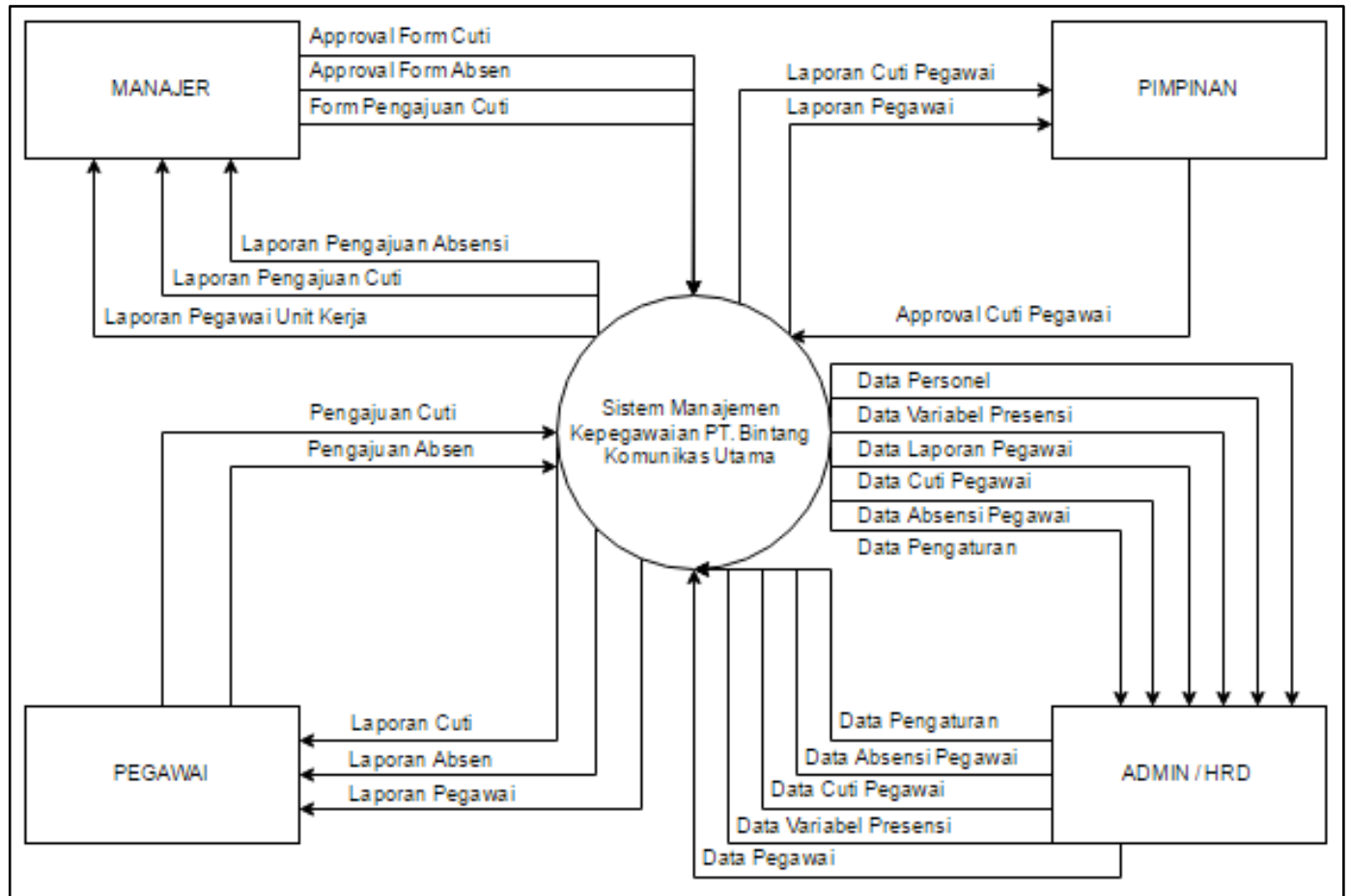

Gambar 3.4 Data Flow Diagram Level 0

Pada DFD level 0 ini terdapat 4 entitas luar yaitu, user sebagai pengguna system. Manajer sebagai user yang otoritasnya diatas user, melihat laporan data unit kerjanya, melakukan approval untuk pengajuan cuti dan absensi pegawai. Pimpinan melihat laporan secara keseluruhan dan melakukan approval utnuk pengajuan cuti dan absensi yang diajukan para manajer. Dan admin sebagai pengelola sistem secara keseluruhan.

\section{DFD Level 1}

DFD level 1 merupakan representasi dari data DFD level 0 yang sudah dipartisi untuk memberikan penjelasan yang lebih detail. Pada sistem manajemen kepegawaian ini terdiri dari data

\section{JISICOM (Journal of Information System, Informatics and Computing)}

http://journal.stmikjayakarta.ac.id/index.php/jisicom Telp.+62-21-3905050, e-mail:jisicom@stmikjayakarta.ac.id, jisicom2017@gmail.com 
personel (proses olah data pegawai, proses olah data unit kerja, proses olah data jabatan, proses oleh data golongan), data variabel presensi (proses olah data jam kerja, proses olah data hari libur, proses olah data dinas luar, proses olah data jadwal proses olah data pengumuman).

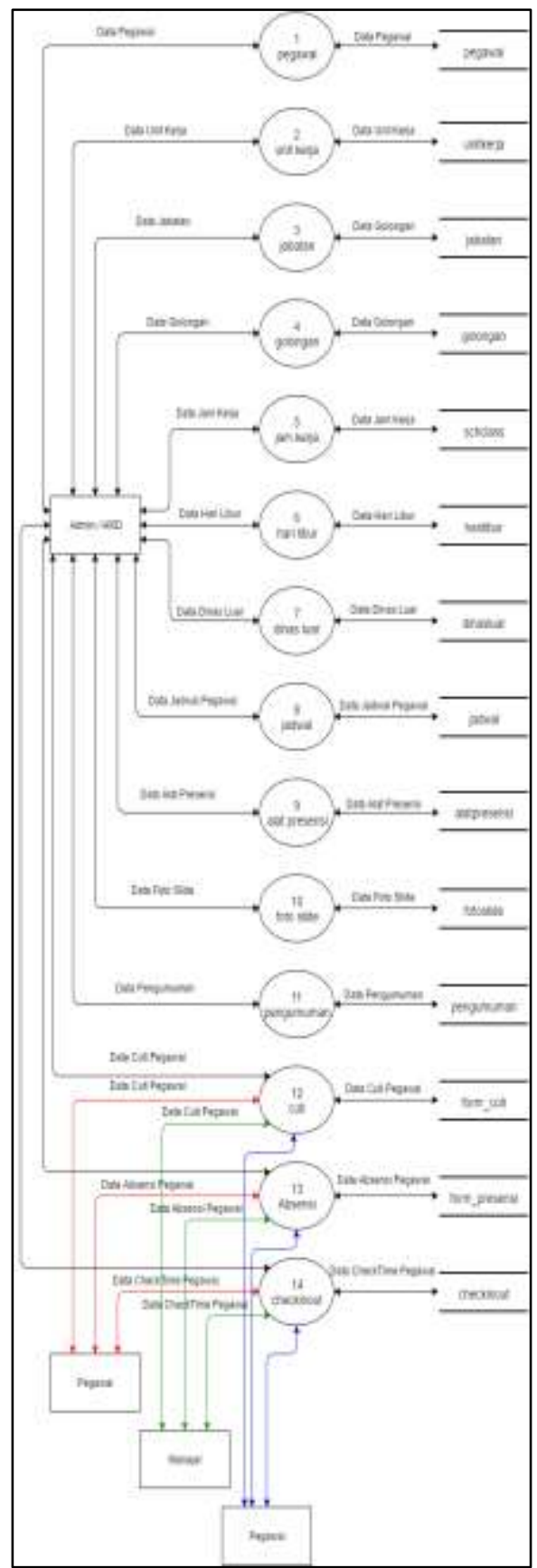

pegawai). Proses olah data cuti pegawai, proses olah data absensi pegawai, dan pengaturan (proses olah data mesin presensi, proses oleh data slider home,

Gambar 3.5 Data Flow Diagram level 1

\subsubsection{Relasi Antar Tabel (RAT)}

Pemakaian istilah "model keterhubunganentitas" dalam bahasa indosensia dapat digunakan sebagai padanan arti istilah asing : Entity Relationship Model ( E - R Model ). Akan tetapi, istilah model Entity Relationship telah demikian umum digunakan dalam berbagai pembahasan tentang analisa/ perancangan basis data.

Pada model entity relationship, data yang ada di dunia nyata diterjemahkan dengan memanfaatkan sejumlah perangkat konseptual menjadi sebuah diagram data yang umum disebut sebagai diagram ER. Sebelum kita membahas lebih jauh tentang diagram E-R tersebut dapat kita gambarkan, maka yang lebih dulu kita ketahui adalah komponen pembentuk model $\mathrm{n}$ E-R. Sesuai namanya, ada dua komponen utama pembentuk model E-R, yaitu Entitas (Entity) dan Relasi (Relation) kedua komponen ini dideskripsikan lebih jauh melalui sejumlah atribut.

JISICOM (Journal of Information System, Informatics and Computing)

http://journal.stmikjayakarta.ac.id/index.php/jisicom Telp.+62-21-3905050, e-mail:jisicom@stmikjayakarta.ac.id, jisicom2017@gmail.com 


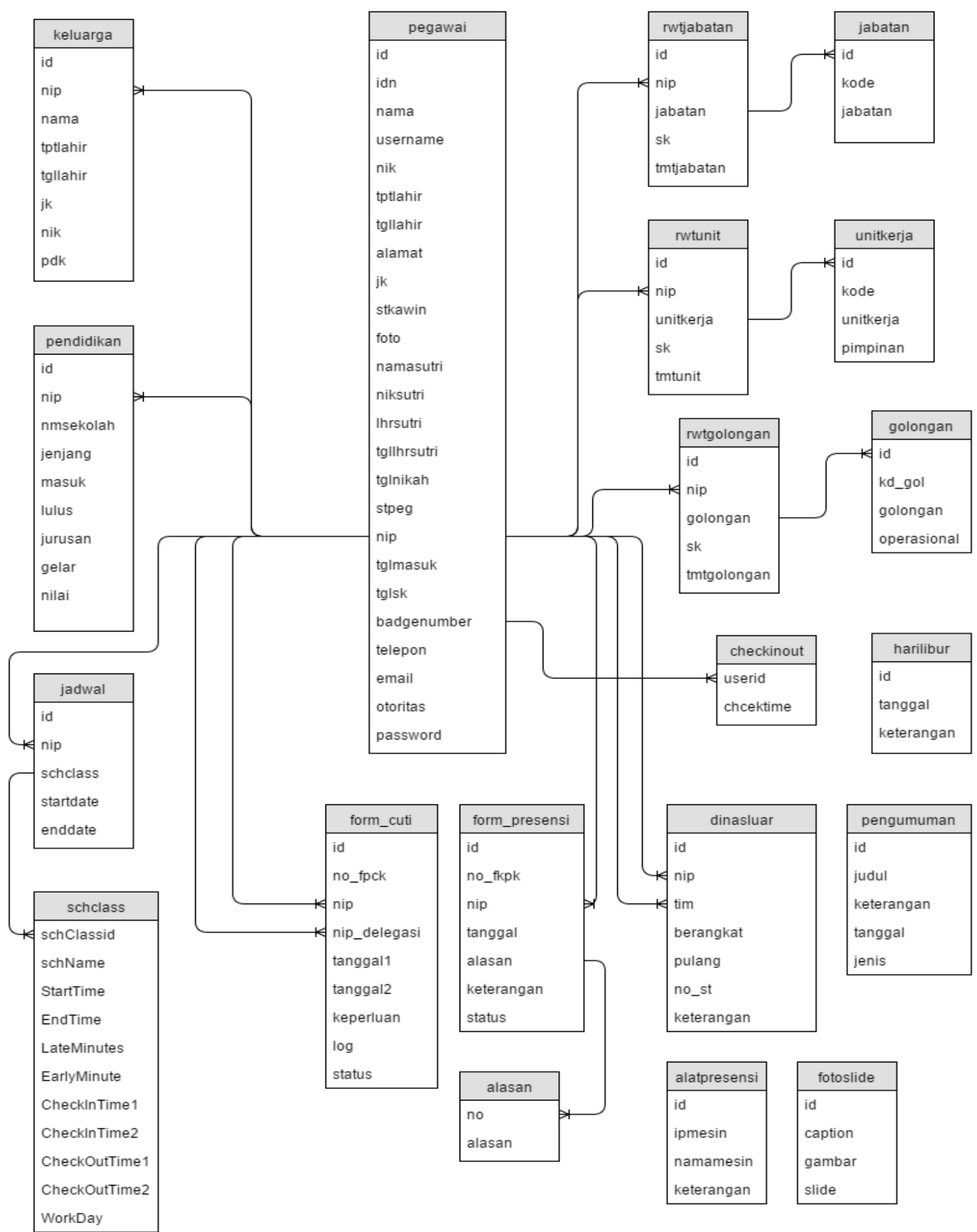

Gambar 3.6 Relasi Antar Tabel Sistem Manajemen Kepegawaian

JISICOM (Journal of Information System, Informatics and Computing) http://journal.stmikjayakarta.ac.id/index.php/jisicom Telp.+62-21-3905050, e-mail: jisicom@stmikjayakarta.ac.id, jisicom2017@gmail.com 


\section{Rancangan Halaman Login}

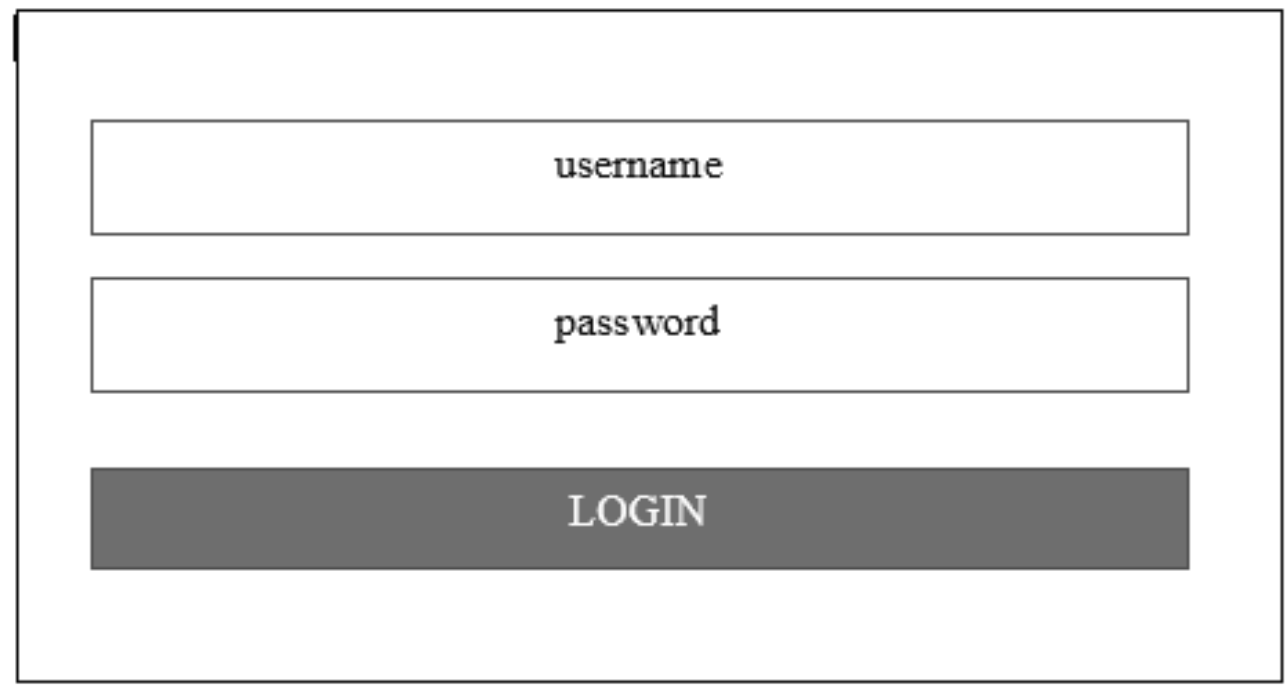

Gambar 3.7 Rancangan Halaman Login

\section{Rancangan input data suami/istri}

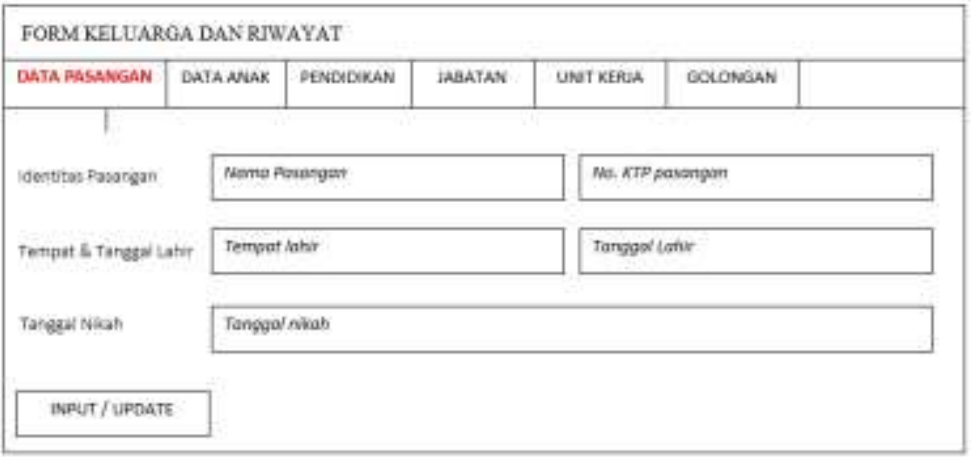

Gambar 3.8 Rancangan menu input data suami/istri dan Jabatan

\section{Rancangan input data anak}

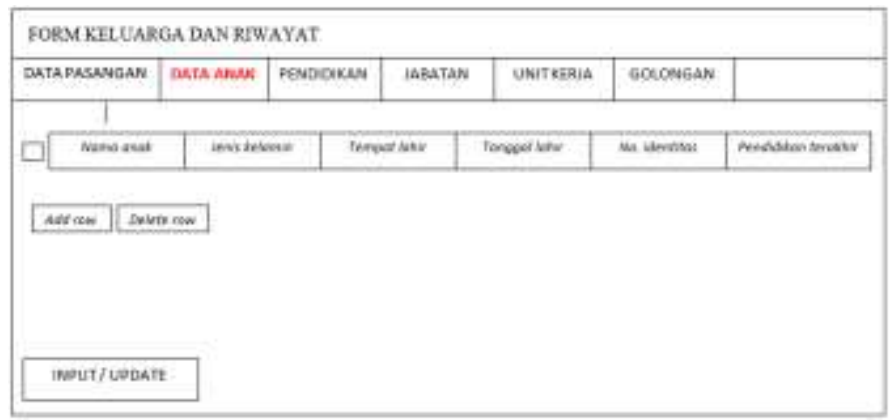

Gambar 3.8 Rancangan menu input data anak

JISICOM (Journal of Information System, Informatics and Computing) http://journal.stmikjayakarta.ac.id/index.php/jisicom Telp.+62-21-3905050, e-mail:jisicom@stmikjayakarta.ac.id, jisicom2017@gmail.com 
Rancangan output data pegawai

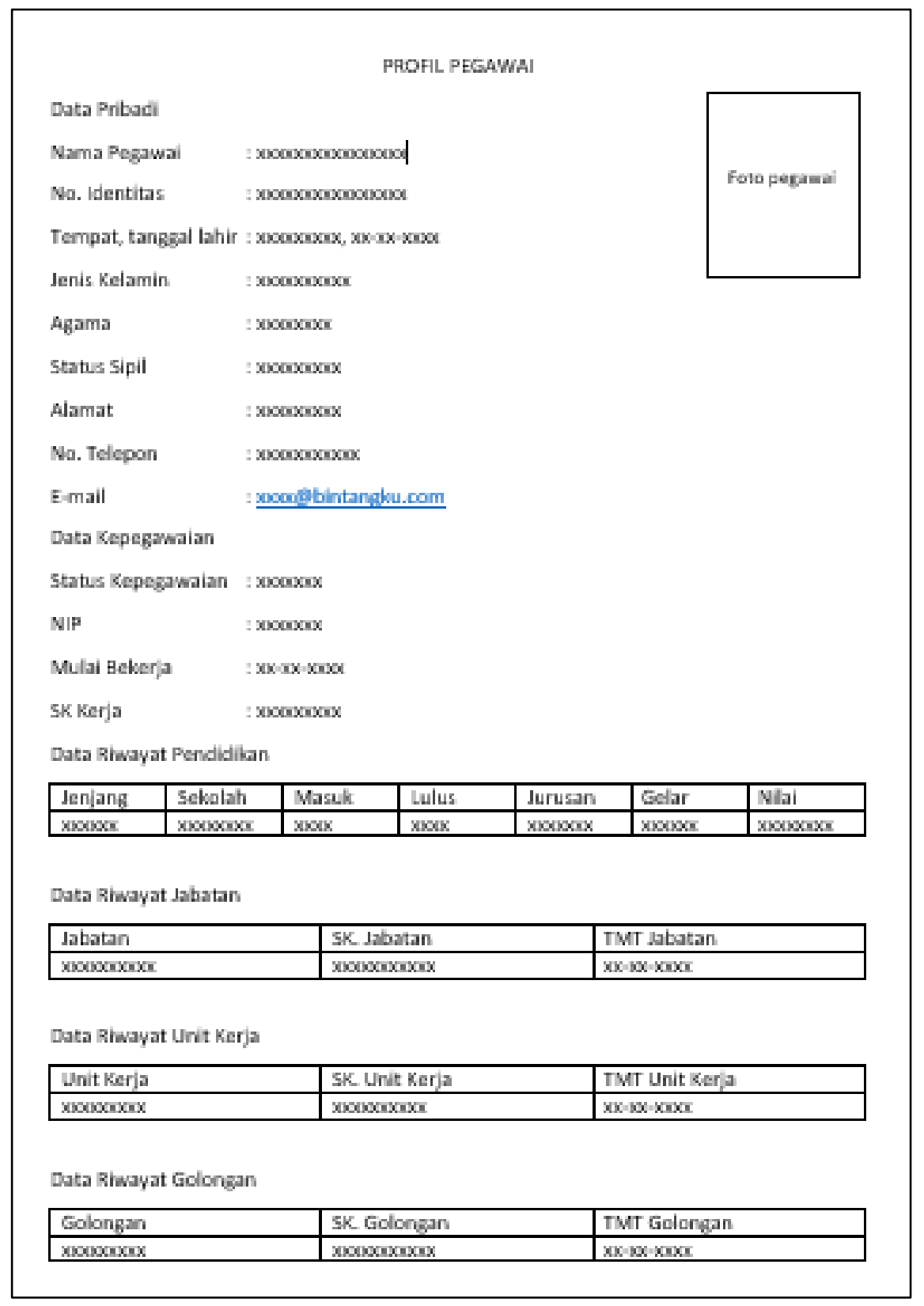

Gambar 3.9 Rancangan output data pegawai

JISICOM (Journal of Information System, Informatics and Computing)

http://journal.stmikjayakarta.ac.id/index.php/jisicom Telp.+62-21-3905050,

e-mail:jisicom@stmikjayakarta.ac.id, jisicom2017@gmail.com 
Rancangan input dan output data unit kerja

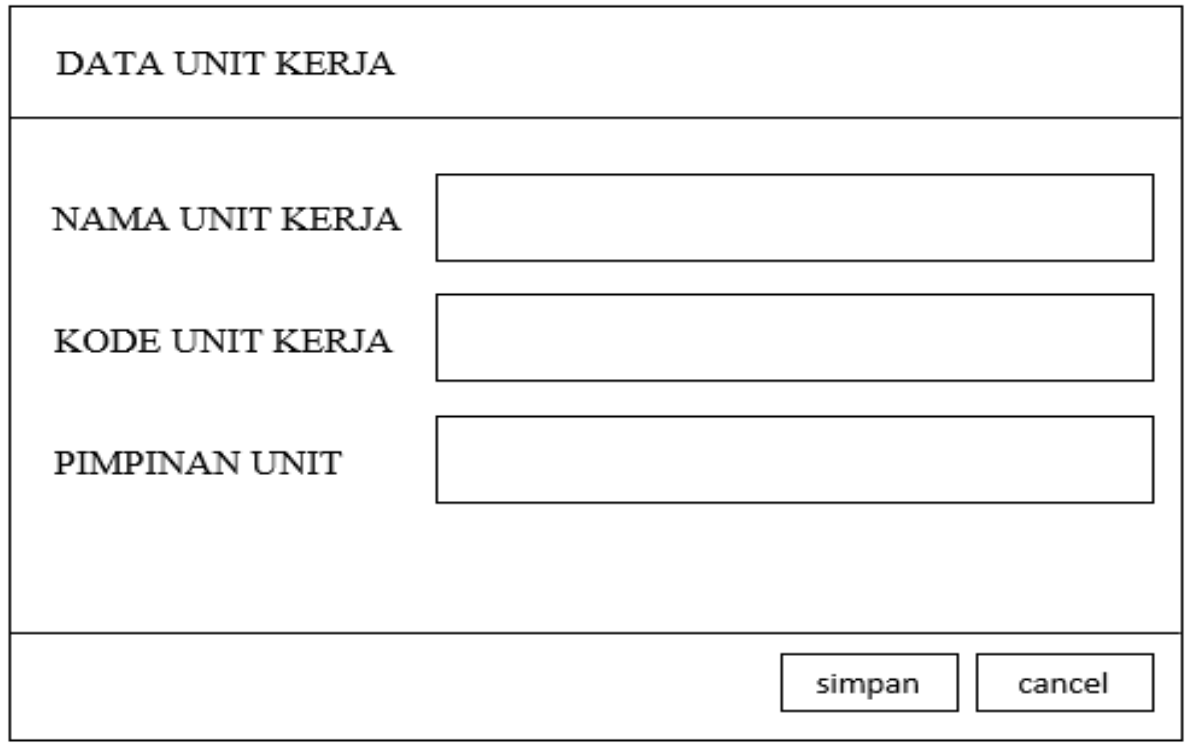

Gambar 3.10 Rancangan menu input data unit kerja

\section{Rancangan input dan output data jabatan}

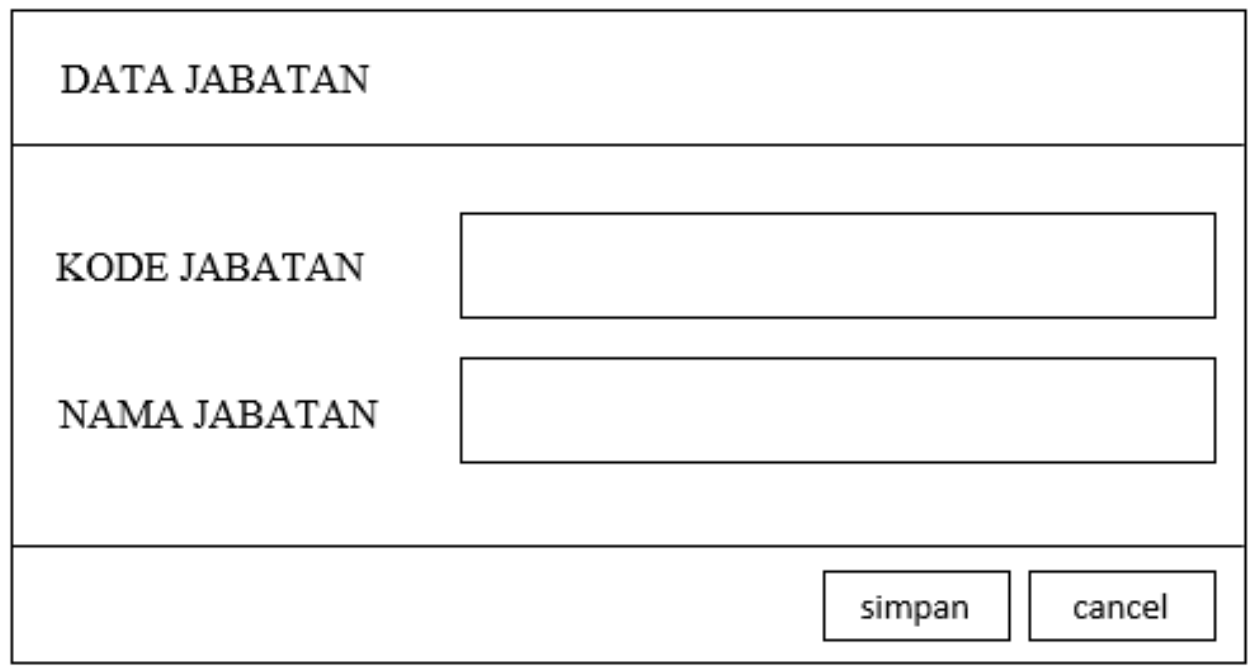

Gambar 4.11 Rancangan menu input data jabatan

JISICOM (Journal of Information System, Informatics and Computing)

http://journal.stmikjayakarta.ac.id/index.php/jisicom Telp.+62-21-3905050, e-mail: jisicom@stmikjayakarta.ac.id, jisicom2017@gmail.com 
Rancangan input dan output data golongan

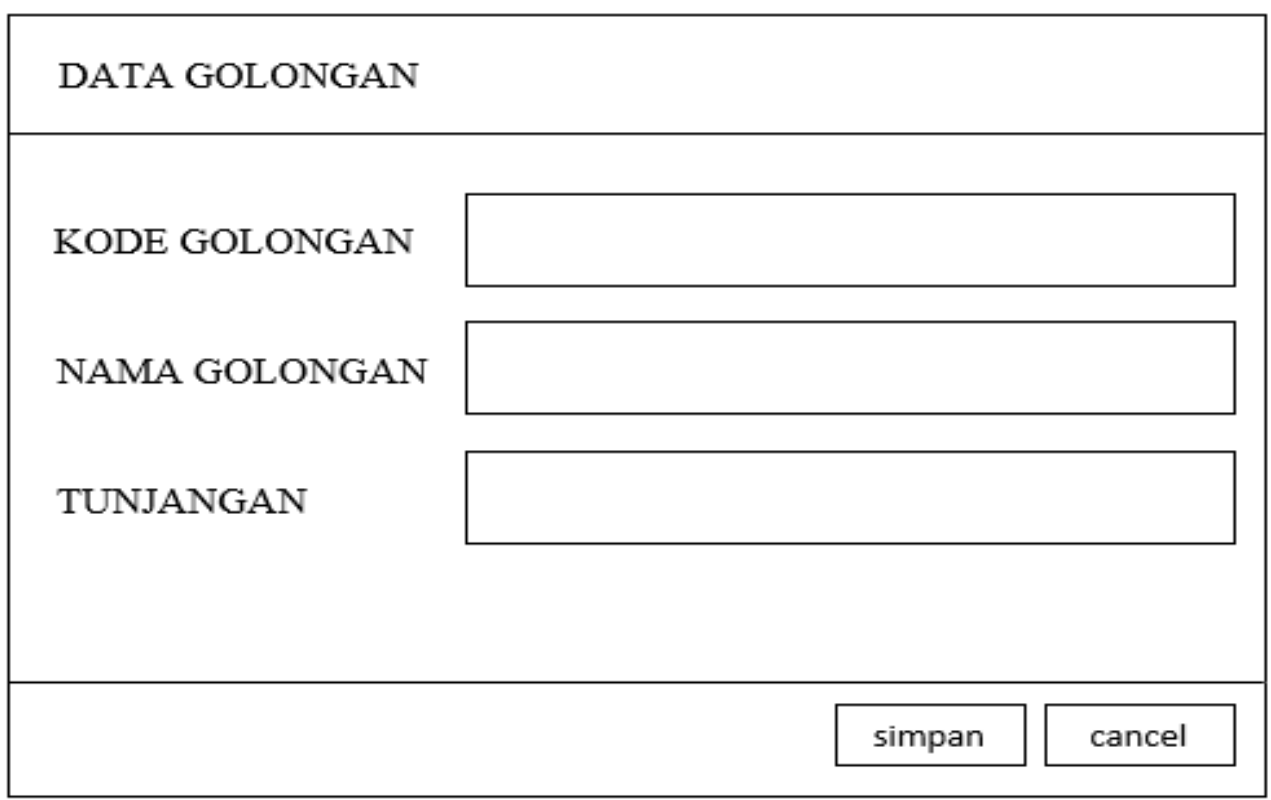

Gambar 3.12 Rancangan menu input data golongan

Rancangan input dan output data jam kerja

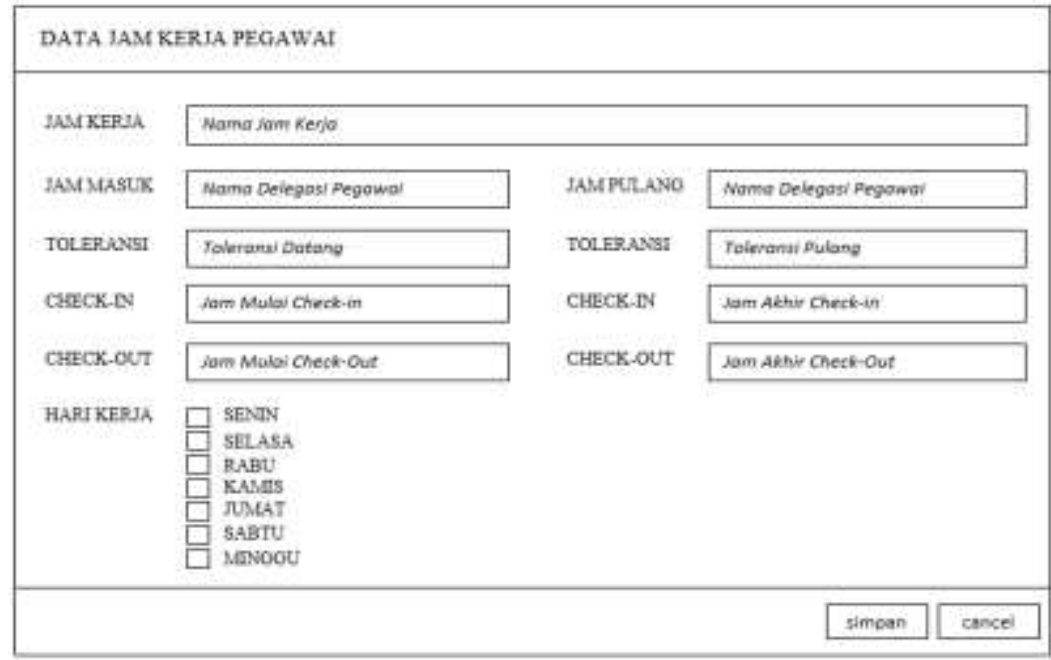

Gambar 3.13 Rancangan menu input data jam kerja

JISICOM (Journal of Information System, Informatics and Computing)

http://journal.stmikjayakarta.ac.id/index.php/jisicom Telp.+62-21-3905050, e-mail: jisicom@stmikjayakarta.ac.id, jisicom2017@gmail.com 
Rancangan input dan output data hari libur

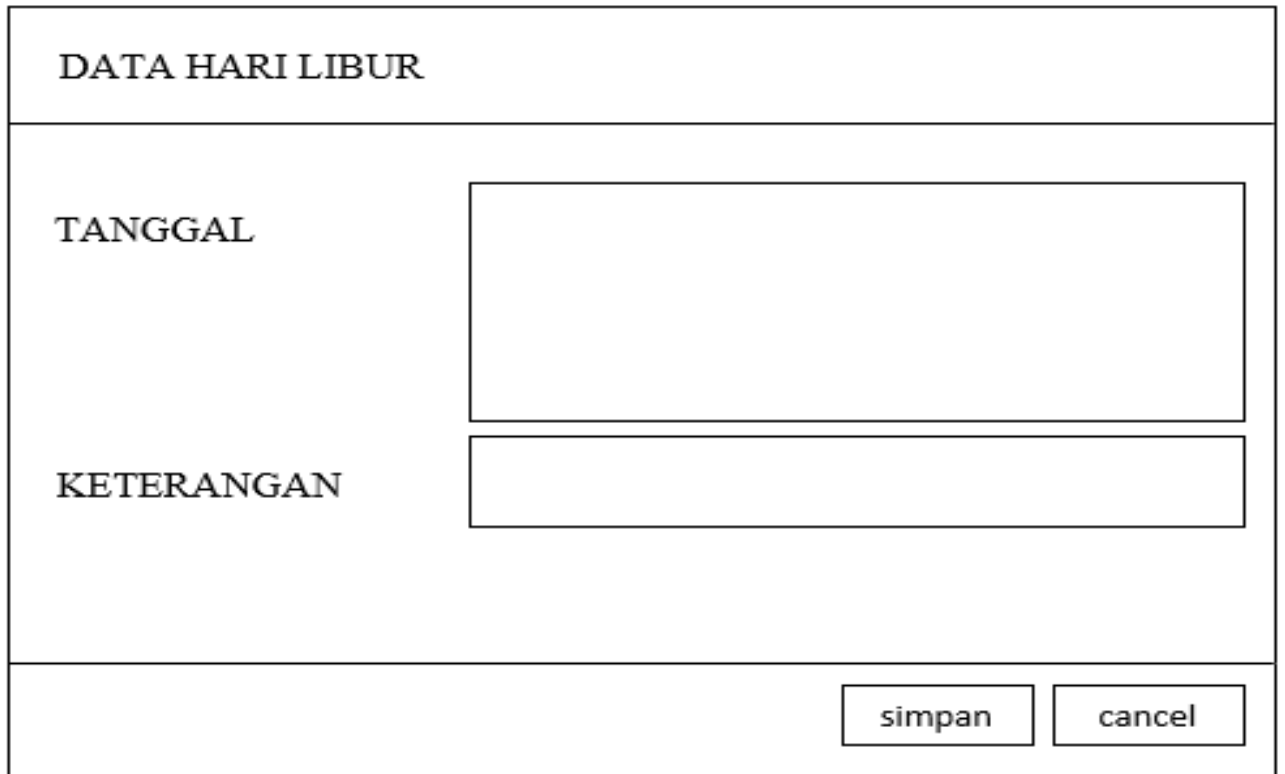

Gambar 3.14 Rancangan menu input data hari libur

Rancangan input dan output data dinas luar

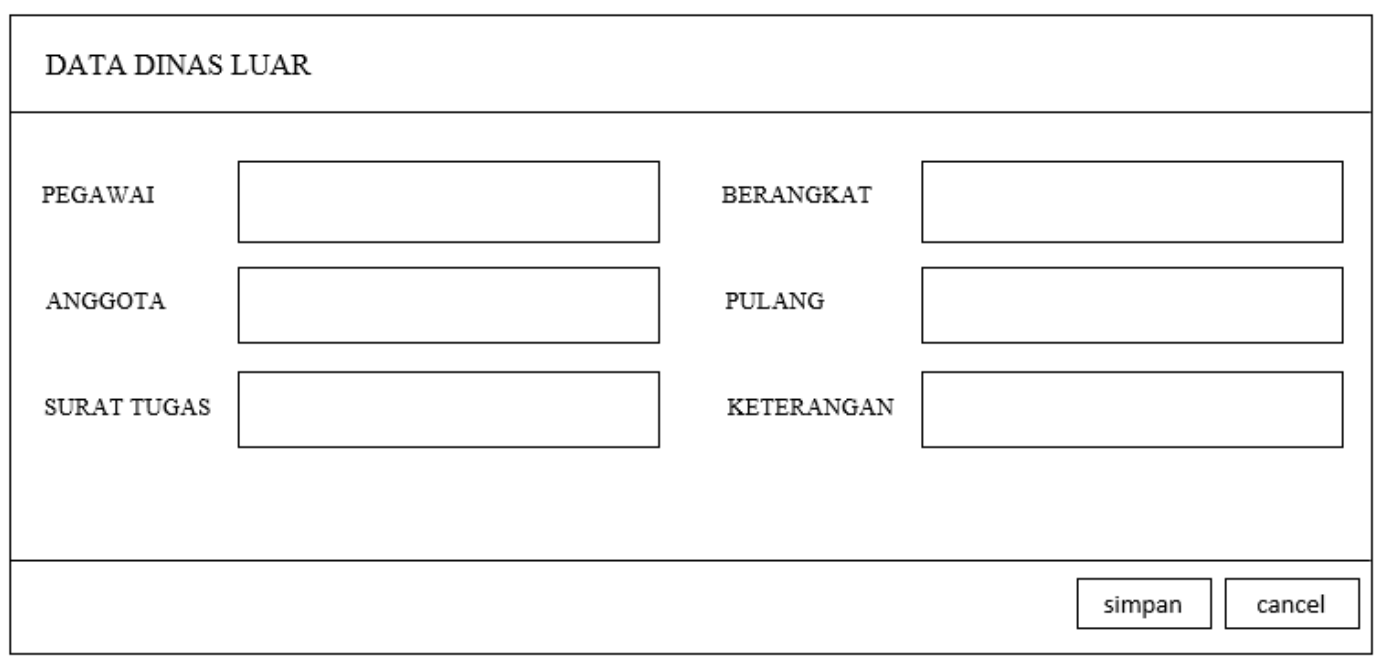

Gambar 3.15 Rancangan menu input data dinas luar

JISICOM (Journal of Information System, Informatics and Computing)

http://journal.stmikjayakarta.ac.id/index.php/jisicom Telp.+62-21-3905050, e-mail:jisicom@stmikjayakarta.ac.id, jisicom2017@gmail.com 
Rancangan input dan output data jadwal pegawai

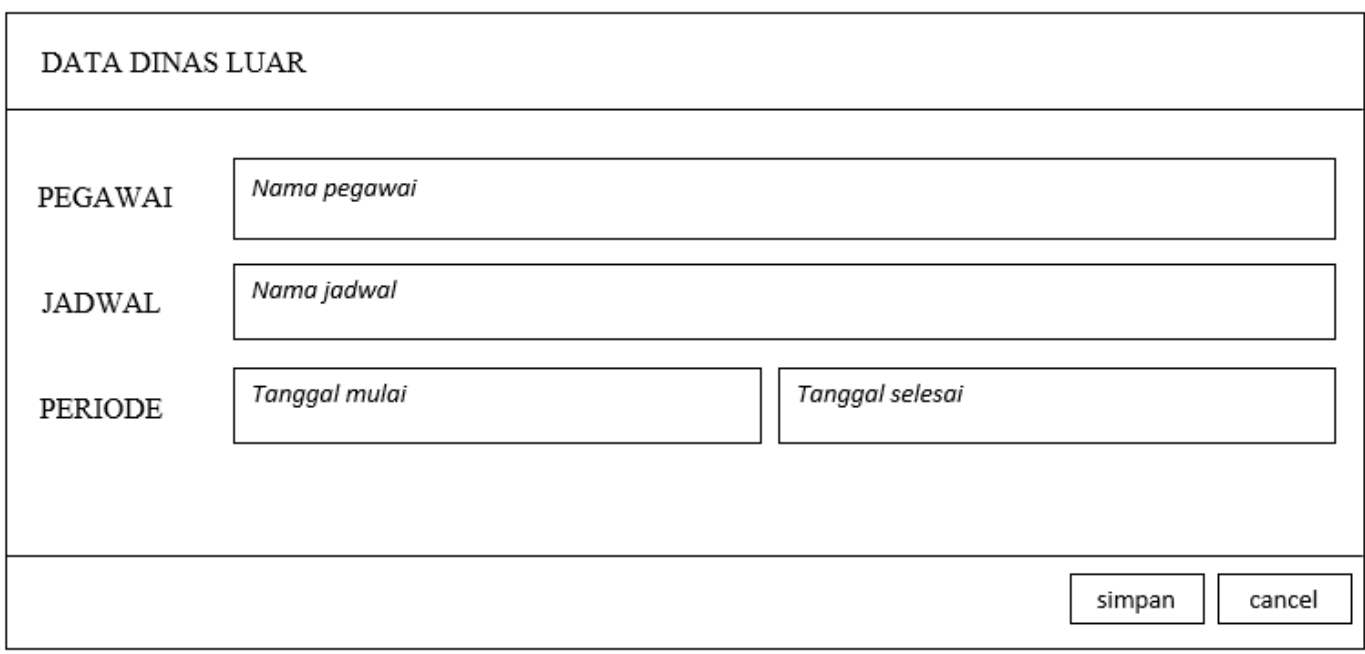

Gambar 3.16 Rancangan menu input data jadwal pegawai

\section{Rancangan output laporan harian}



Gambar 3.17 Rancangan tabel data laporan harian

JISICOM (Journal of Information System, Informatics and Computing) http://journal.stmikjayakarta.ac.id/index.php/jisicom Telp.+62-21-3905050, e-mail: jisicom@stmikjayakarta.ac.id, jisicom2017@gmail.com 
Ranacangan output laporan pegawai

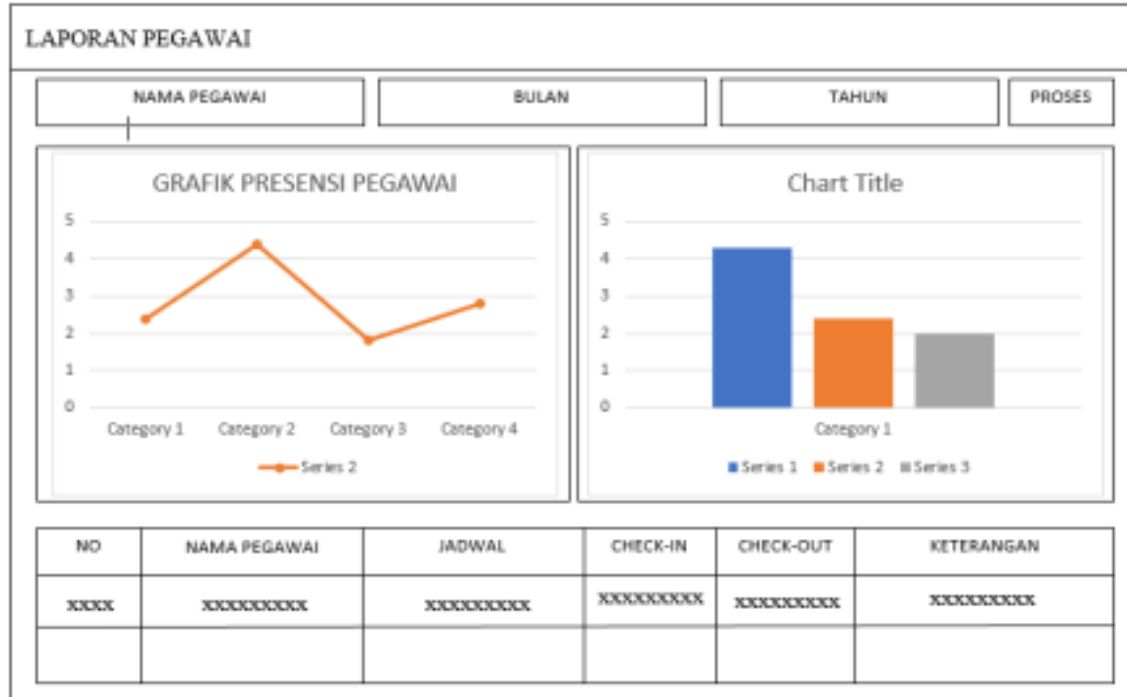

Gambar 3.18 Rancangan output laporan pegawai

4.4.4.1 Rancangan laporan potongan pegawai

\begin{tabular}{|c|c|c|c|c|}
\hline \multicolumn{5}{|c|}{ POTONGAN TUNIANGAN } \\
\hline \multicolumn{5}{|c|}{ No. $x x x x x x x / x x / x x x x$} \\
\hline Nama & \multicolumn{4}{|c|}{ 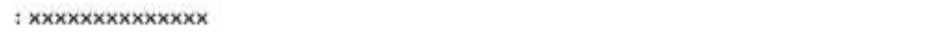 } \\
\hline NIP & \multicolumn{4}{|l|}{$: x x x x x x x$} \\
\hline Golongan & \multicolumn{4}{|l|}{$: x \times x x x x x x x x$} \\
\hline Tunjangan & \multicolumn{2}{|l|}{ : Rp. $\mathbf{x x x} \cdot \mathbf{x} \times \mathbf{x}$} & Potongan & :Rp. $x x \cdot x \times x$ \\
\hline Periode & \multicolumn{2}{|c|}{ : $x x-x \operatorname{xxx}(x x$ hari kerja) } & Jam Kerja & : $x x x$ Jam $x x$ Menit \\
\hline \multicolumn{2}{|c|}{ Potongan Terlambat (1) } & $: x x(x) R p, x x, x x x$ & & \\
\hline \multicolumn{2}{|c|}{ Potongan Pulang cepat (2) } & $: x x(x)$ Rp. $x x \cdot x x x \mid$ & & \\
\hline \multicolumn{2}{|c|}{ Potnganan tidak masuk (3) } & $: x x(x)$ Rp. $x x \cdot x x x$ & $(1)+(2)+(3$ & $=$ Rp. $x \times x \cdot x \times x$ \\
\hline \multicolumn{2}{|c|}{ Total Potongan } & : Rp. $x \times x \cdot x \times x$ (terbilang) & & \\
\hline \multicolumn{3}{|c|}{ Diajukan Oleh, } & & Mengotahui \\
\hline KEUANGA & & & & HRD \\
\hline
\end{tabular}

Gambar 3.19 Rancangan laporan potongan tunjangan

JISICOM (Journal of Information System, Informatics and Computing)

http://journal.stmikjayakarta.ac.id/index.php/jisicom Telp.+62-21-3905050,

e-mail:jisicom@stmikjayakarta.ac.id, jisicom2017@gmail.com 
Rancangan laporan unit kerja

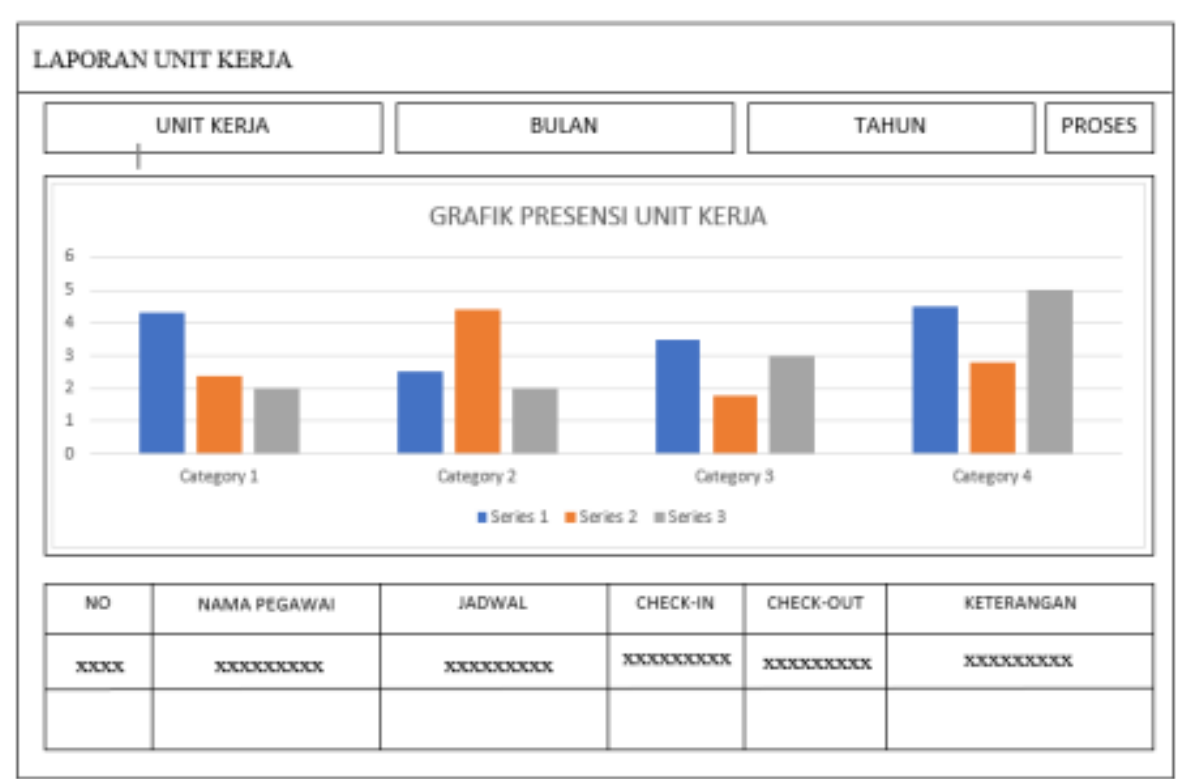

Gambar 3.20 Rancangan laporan unit kerja

\section{Rancangan input dan output data cuti pegawai}

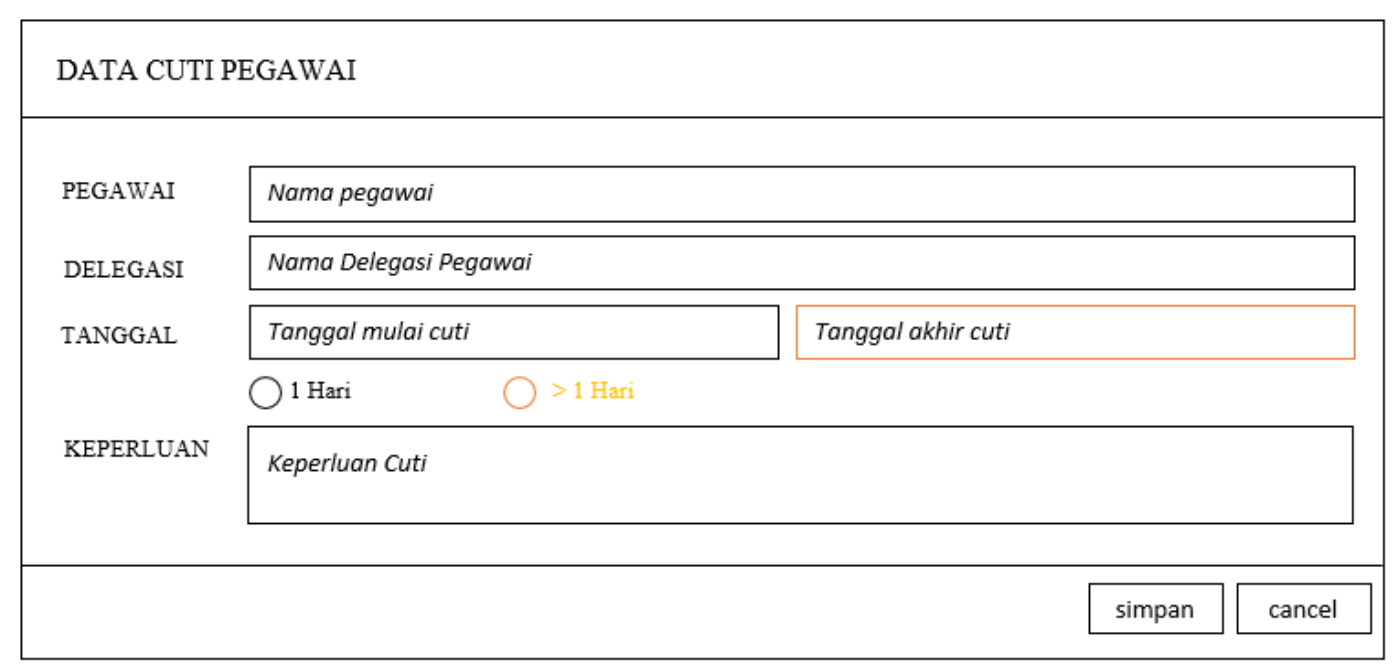

Gambar 3.21 Rancangan menu input data cuti pegawai

JISICOM (Journal of Information System, Informatics and Computing)

http://journal.stmikjayakarta.ac.id/index.php/jisicom Telp.+62-21-3905050, e-mail:jisicom@stmikjayakarta.ac.id, jisicom2017@gmail.com 


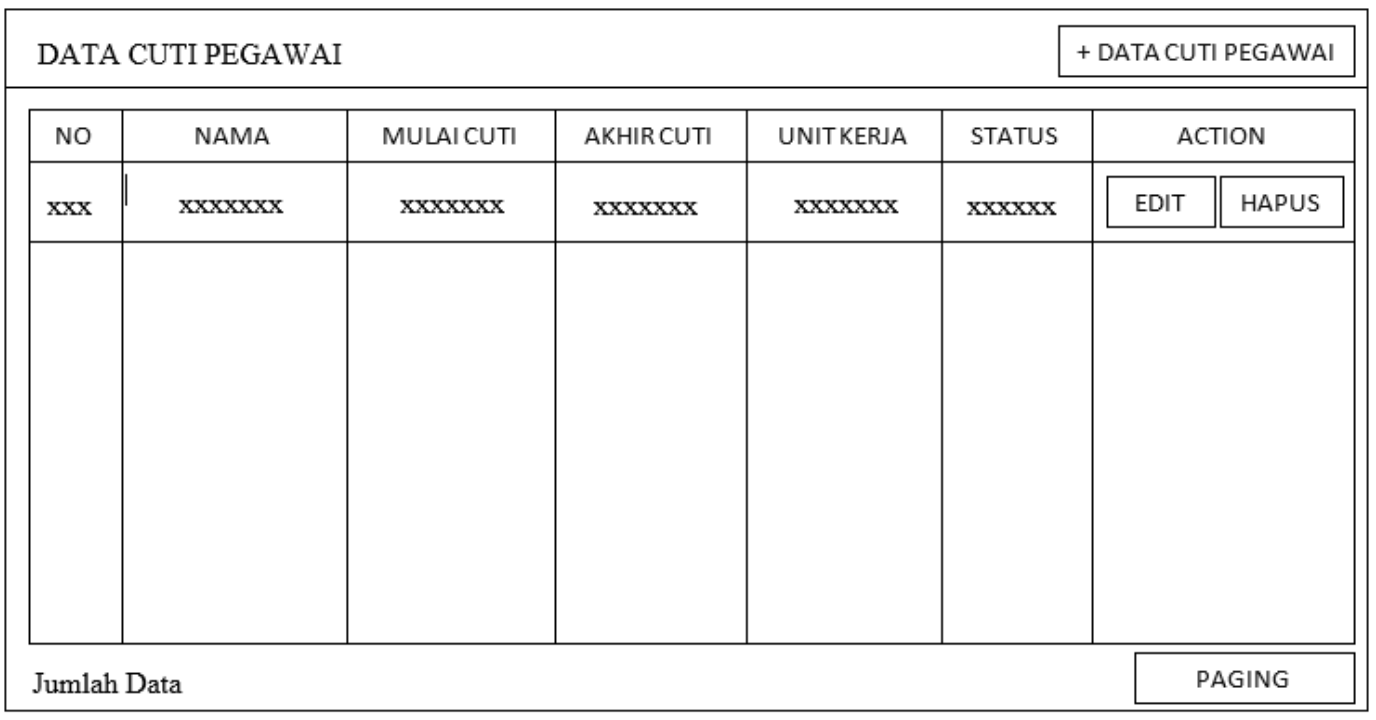

Gambar 3.22 Rancangan tabel output data cuti pegawai

\section{FORM PENGAJUAN CUTI}

no. $x x x x / x x x-x x / x x x / x x / x x x x$

Saya yang bertanda tangan di bawah ini :

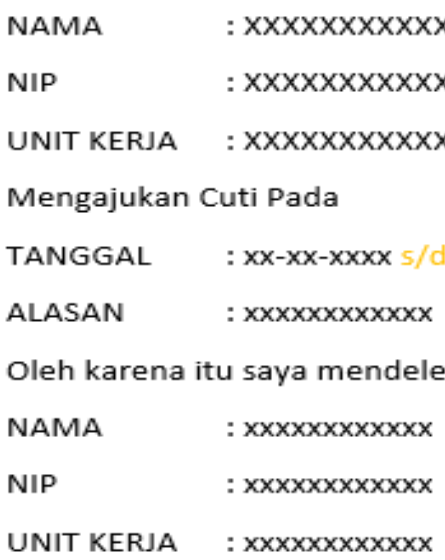

Diajukan Oleh

NAMA PEGAWAI
Menyetujui

PIMPINAN UNIT
Mengetahui

$\underline{\mathrm{HRD}}$

Gambar 3.23 Rancangan output data form cuti

Rancangan input dan output data absensi pegawai

JISICOM (Journal of Information System, Informatics and Computing)

http://journal.stmikjayakarta.ac.id/index.php/jisicom Telp.+62-21-3905050,

e-mail:jisicom@stmikjayakarta.ac.id, jisicom2017@gmail.com 


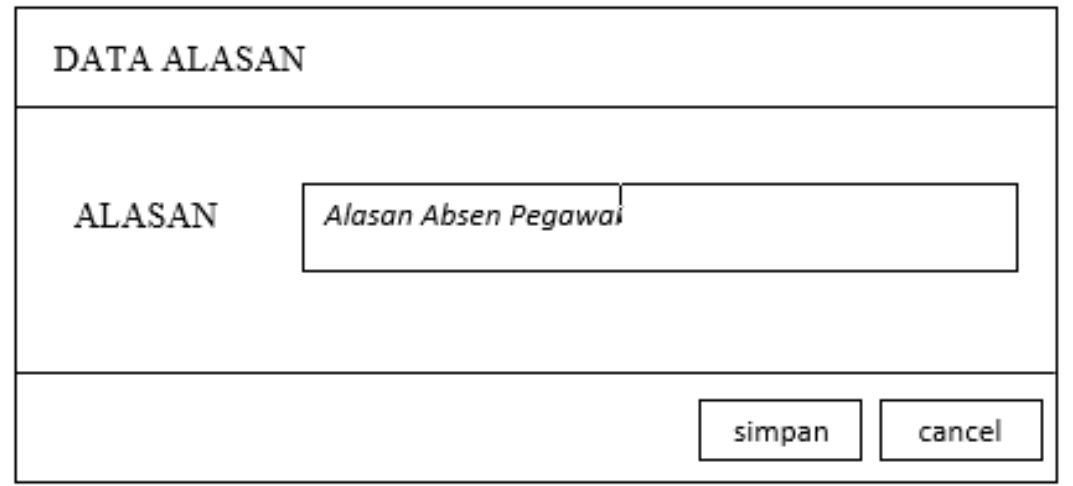

Gambar 3.24 Rancangan menu input data alasan absensi

\begin{tabular}{|c|c|c|c|}
\hline \multicolumn{4}{|c|}{ DATA ABSENSI PEGAWAI } \\
\hline PEQAWAI & Nomo pegonoi & & \\
\hline TANOOAL & Tanggow & & \\
\hline ALASAN & Alasan Absen & & \\
\hline KETERANOAN & Keterangan & & \\
\hline & & simpan & cancel \\
\hline
\end{tabular}

Gambar 3.25 Rancangan menu input data keterangan absensi pegawai

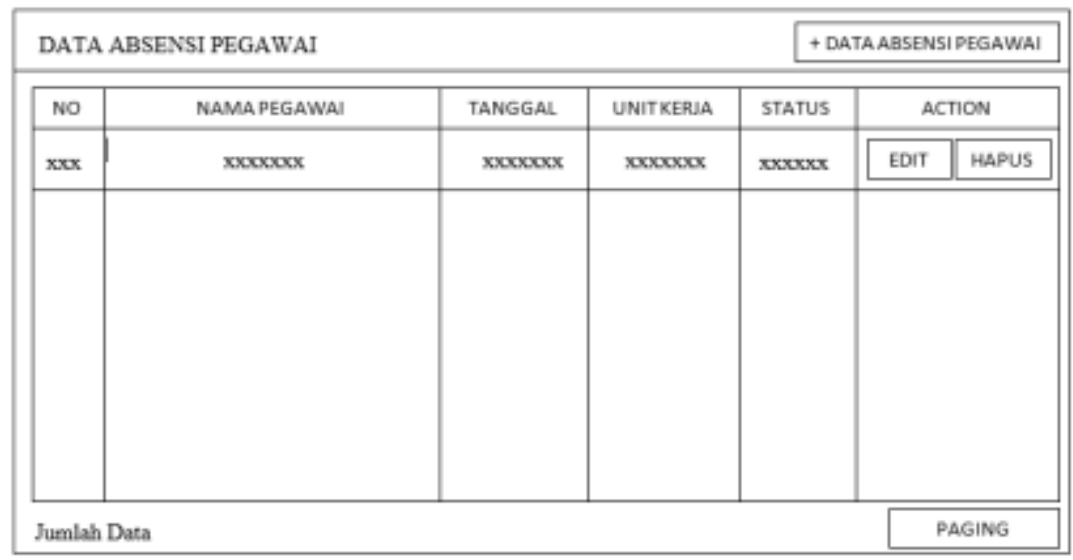

Gambar 3.26 Rancangan tabel data absensi pegawai 


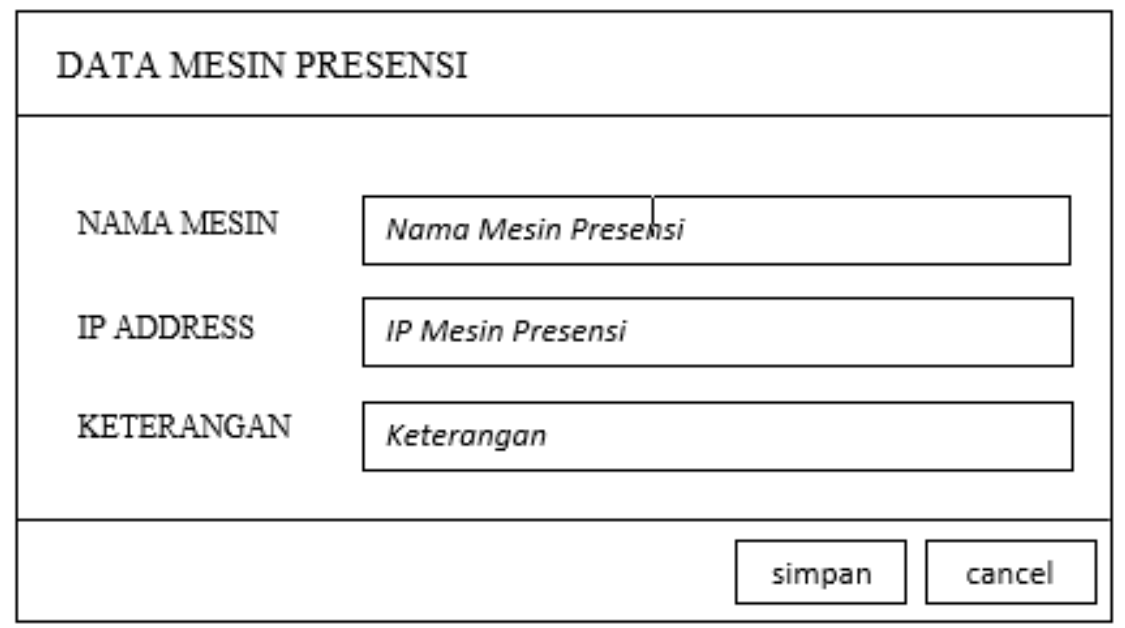

Gambar 3.27 Rancangan output data form ketarangan absensi pegawai

Rancangan input dan output data mesin presensi

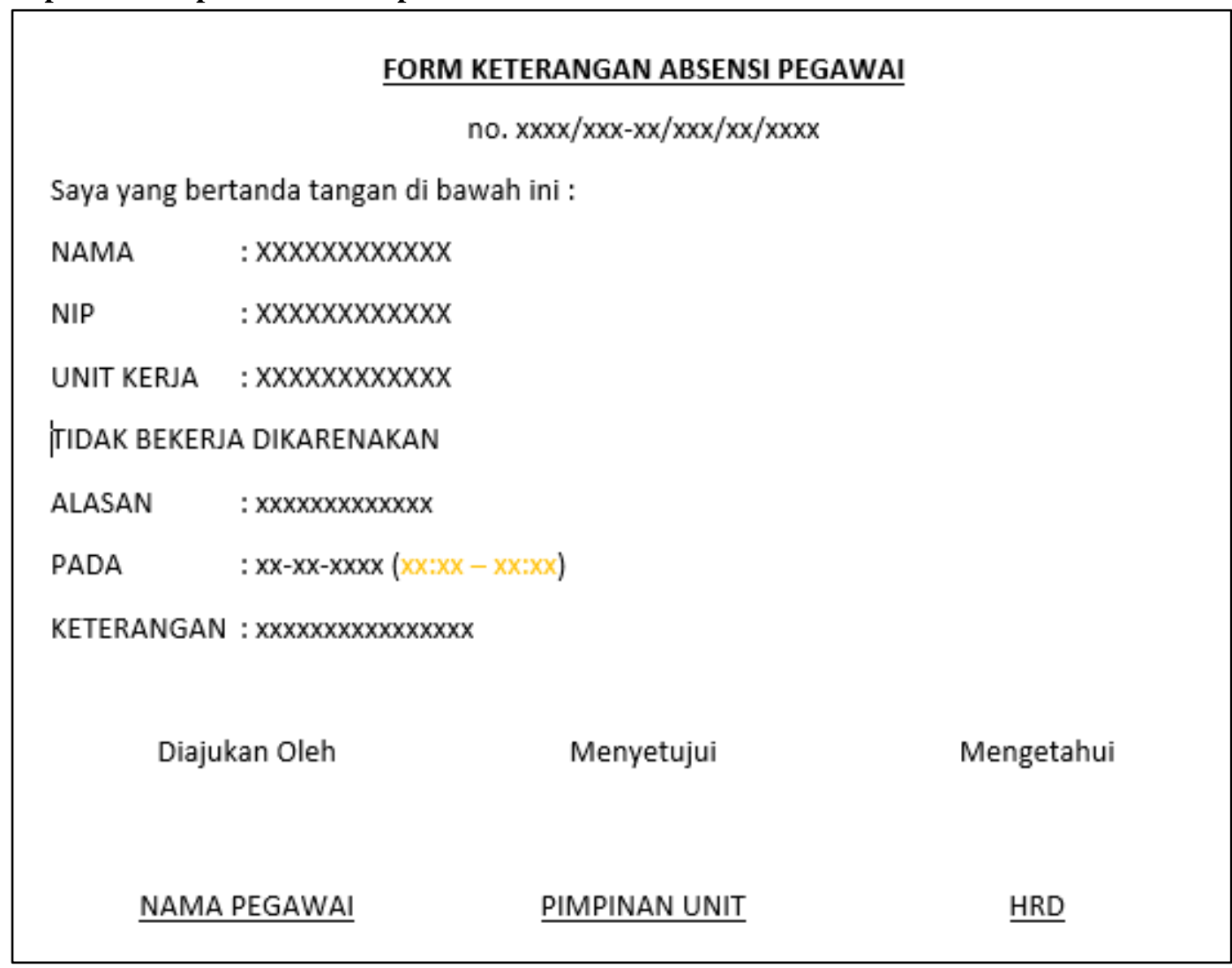

Gambar 3.28 Rancangan menu input data mesin presensi

JISICOM (Journal of Information System, Informatics and Computing)

http://journal.stmikjayakarta.ac.id/index.php/jisicom Telp.+62-21-3905050, e-mail: jisicom@stmikjayakarta.ac.id, jisicom2017@gmail.com 


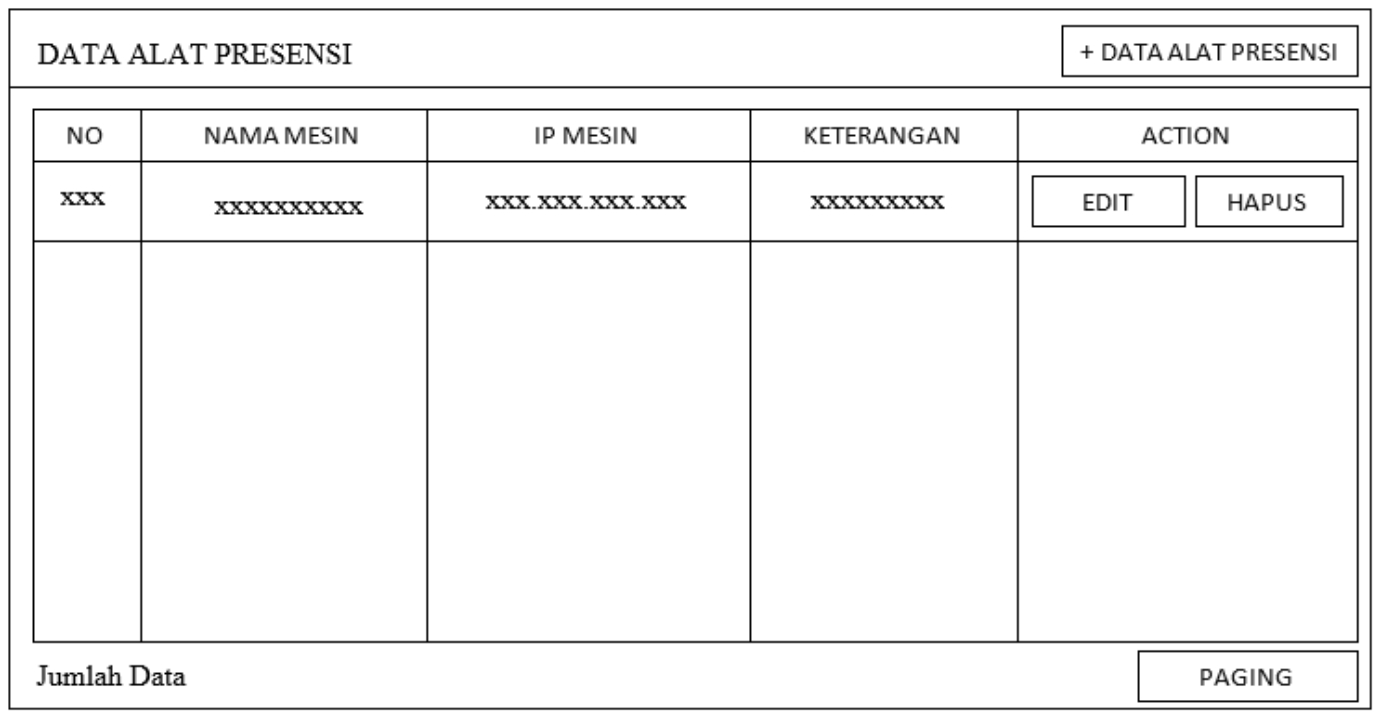

Gambar 3.29 Rancangan tabel data mesin presensi

Rancangan input dan output data slider

\begin{tabular}{|c|c|c|c|}
\hline \multicolumn{4}{|c|}{ DATA GAMBAR SLIDE } \\
\hline JUDUL & Judul foto & & \\
\hline SLIDE & Publikasi slide & & \\
\hline \multirow[t]{2}{*}{ GAMBAR } & Choose file & & \\
\hline & & simpan & cancel \\
\hline
\end{tabular}

Gambar 3.30 Rancangan menu input data gambar slide 


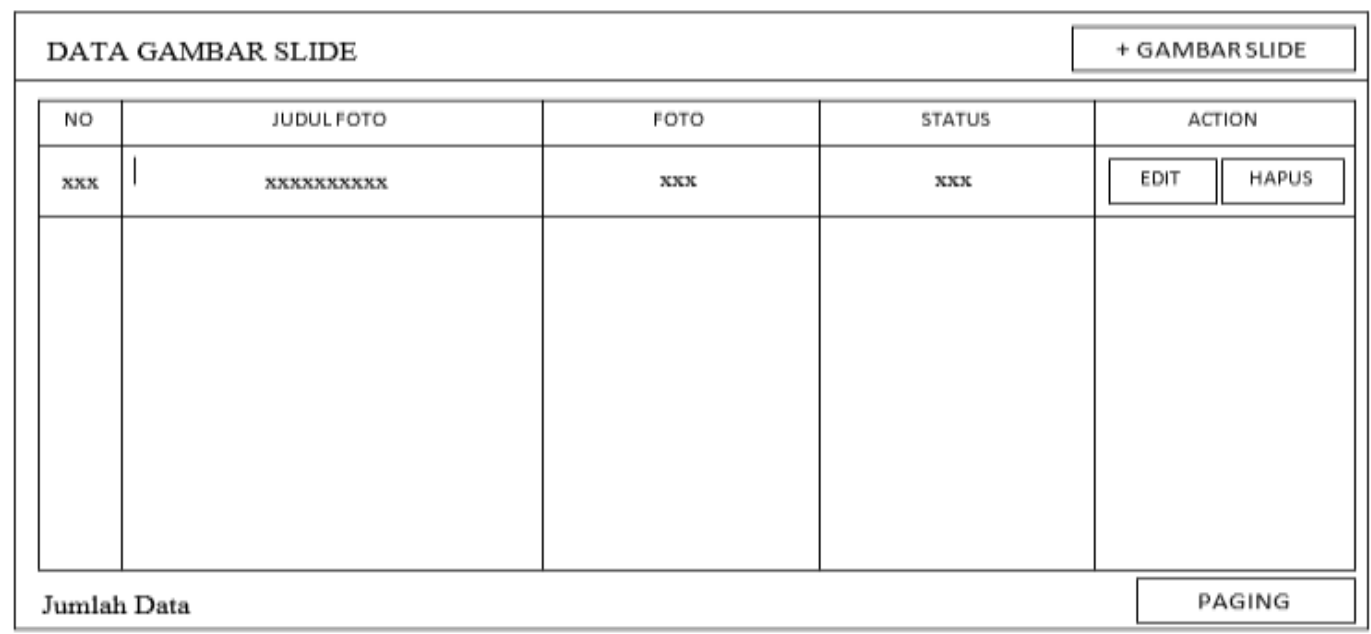

Gambar 3.31 Rancangan tabel data gambar slide

Rancangan input dan output data pengumuman

\begin{tabular}{|c|c|c|c|}
\hline \multicolumn{4}{|c|}{ DATA PENGUMUMAN } \\
\hline JENIS INFORMASI & Jenis Informasi & & \\
\hline TANGGAL & Tanggal kegiatan & & \\
\hline JUDUL & Judul Informasi & & \\
\hline \multirow[t]{2}{*}{ DETAIL KEGIATAN } & Detail Kegiatan & & \\
\hline & & simpan & cancel \\
\hline
\end{tabular}

Gambar 3.32 Rancangan menu input data pengumuman 


\section{Journal of Information System, Informatics and Computing}

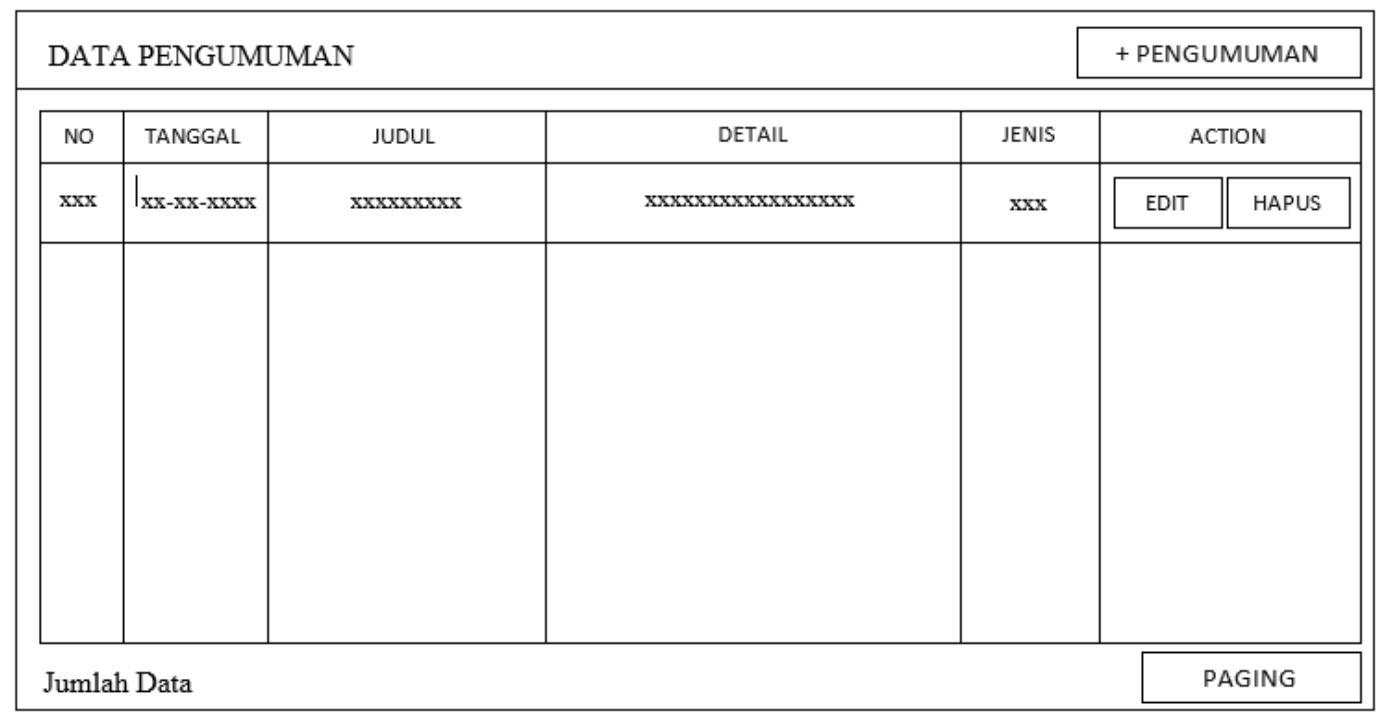

Gambar 3.33 Rancangan tabel data pengumuman

\section{KESIMPULAN}

Setelah melakukan proses perancangan dan pembuatan sistem manajemen kepegawaian di PT. Bintang Komunikasi Utama, penulis menemukan beberapa hal yang perlu untuk disimpulkan yaitu :

1. Untuk menjamin keamanan data, otoritas pengguna sebagai hak akses masuk ke dalam sistem sangatlah penting, karena sebagaian data hanya boleh diakses oleh pengguna tertentu dalam menjalankan fungsinya.

2. Sistem yang dirancang dan dibangun diharapkan dapat mempermudah mengelola data kepegawaian yang ada di PT. Bintang Komunikasi Utama.

\section{REFERENSI}

[1] Al Fata, Hanif. 2007. Analisis dan Perancangan Sistem Informasi. Yogyakarta : Andi Publisher.

[2] Anonim. 2014. Implementasi http://karyatulisilmiah.com/pengertianimplementasi diakses tanggal 15 November 2016

[3] Anonim, $2016 . \quad$ Bootstrap http://www.malasngoding.com/pengertiandan-cara-menggunakan-bootstrap/ diakses tanggal 11 Oktober 2016

[4] Departemen Pendidikan Nasional Republik Indonesia. 2008. Kamus Besar Bahasa
Indonesia.

http://badanbahasa.kemdikbud.go.id/kbbi/

[5] Dwiartara, Loka. 2010. Menyelam \& Menaklukan Samudra PHP. Bogor

[6] Fadlullah, Fadul. 2016 Bootstrap http://dul.web.id/bootstrap/3/tutstips/belajar-bootstrap-untuk-pemula.php diakses tanggal 11 Oktober 2016

[7] Febrian, Jack. 2007. Kamus Komputer dan Teknologi Informasi. Bandung : Informatika

[8] Haryanto, Jogiyanti. 2009. Sistem Teknologi Informasi. Yogyakarta : Andi.

[9] Hendrayudi. 2009. Visual Basic 2008 Untuk Berbagai Keperluan Pemrograman. Jakarta : Elex Media Komputindo.

[10] Kadir, Abdul. 2014. Pengenalan Sistem Informasi Edisi Revisi. Yogyakarta : Andi

[11] O'Brien, James A., George M. Marakas (2007), Management Information Systems 10th Edition. New York : McGraw-Hill.

[12] Pressman, Roger S. 2010. Software Engineering : A Practioner's Approach, Seventh Edition. New York : McGraw-Hill.

[13] Prihatna, Henky. 2005. Kiat Praktis Menjadi Webmaster Profesional. Jakarta : Elex Media Komputindo

[14] Putra, Darma. 2009. Sistem Biometrika : Konsep Dasar, Teknik Analisa Citra dan Tahapan Membangun Aplikasi Sistem Biometrika. Yogyakarta : Andi

\section{JISICOM (Journal of Information System, Informatics and Computing)}

http://journal.stmikjayakarta.ac.id/index.php/jisicom Telp.+62-21-3905050, e-mail:jisicom@stmikjayakarta.ac.id, jisicom2017@gmail.com 
[15] Rizky, Soetam. 2011. Konsep Dasar Rekayasa Perangkat Lunak. Surabaya : Prestasi Pustaka Raya.

[16] Saputra, Agus. 2012. Membuat Aplikasi Absensi dan kuisioner untuk panduan skripsi. Jakarta : Elex Media Komputindo.

[17] Suarga. 2010. Algoritma Pemrograman. Yogyakarta : Andi.

[18] Sutarman. 2009. Pengantar Teknologi Informasi. Jakarta : Bumi Aksara.

[19] Wikipedia. 2016. Notepad++ https://id.wikipedia.org/wiki/Notepad++ diakses tanggal 17 Oktober 2016

[20] Wikipedia. 2016. Pemindai Sidik jari https://id.wikipedia.org/wiki/Pemindai _sidik_jari diakses tanggal 10 Oktober 2016

[21] Wikipedia. 2016. Sidik Jari https://id.wikipedia.org/wiki/sidik_jari diakes tanggal 10 Oktober 2016

[22] Wikipedia. 2016. Web Browser https://id.wikipedia.org/wiki/Penjelajah_we $\underline{\mathrm{b}}$ diakses tanggal 12 Oktober 2016

[23] Wikiepdia. XAMPP https://id.wikipedia.org/wiki/XAMPP diakses tanggal 12 Oktober 2016

[24] Yasin, Verdi. 2012. Rekayasa Perangkat Lunak Berorientasi Objek. Bogor : Mitra Wacana Media. 